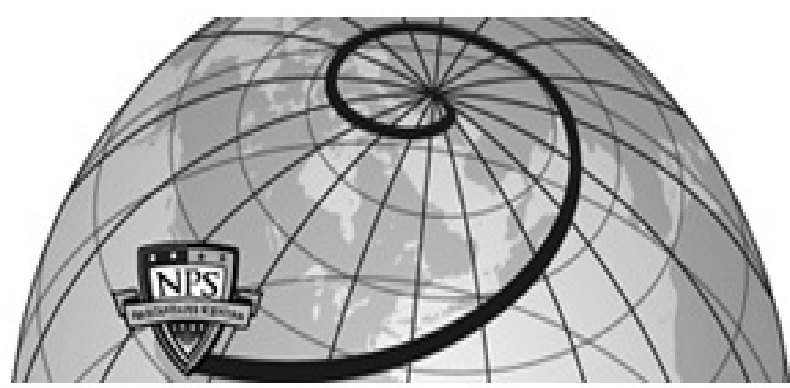

Calhoun: The NPS Institutional Archive DSpace Repository

The Impact of CEO Career Concerns on Accruals Based and Real Earnings Management

Demers, Elizabeth; Wang, Chong

Monterey, California: Naval Postgraduate School.

https://hdl.handle.net/10945/37001

This publication is a work of the U.S. Government as defined in Title 17, United States Code, Section 101. Copyright protection is not available for this work in the United States.

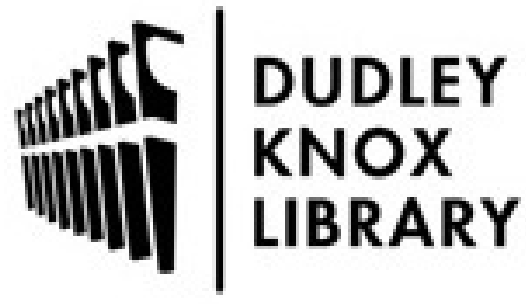

http://www.nps.edu/library
Calhoun is the Naval Postgraduate School's public access digital repository for research materials and institutional publications created by the NPS community. Calhoun is named for Professor of Mathematics Guy K. Calhoun, NPS's first appointed -- and published -- scholarly author.

Dudley Knox Library / Naval Postgraduate School 411 Dyer Road / 1 University Circle Monterey, California USA 93943 


\title{
The Impact of CEO Career Concerns on Accruals Based and Real Earnings Management *
}

\author{
Elizabeth Demers ${ }^{\dagger} \quad$ Chong Wang $^{\ddagger}$
}

November 2010

\begin{abstract}
The point of our study is to investigate, using both theoretical and archival empirical methods, the role of CEO career concerns as a determinant of earnings management behavior. The significance of earnings management in market economies is well documented. Our investigations are motivated by the disconnect between recent survey evidence documenting that executives prioritize implicit contracting (i.e., labor market) concerns when making earnings management decisions (Graham et al (2005)) and the extant academic literature's focus on explicit contracting explanations. We first develop a model of earnings management, rooted in career concerns, that alternatively incorporates the features of the accrual accounting performance measurement system and the negative value-destroying effects of real activities earnings management. Our model leads to the surprising prediction that, absent explicit compensation contracts, managers do not engage in income-increasing earnings management early in their careers. By contrast, later career stage CEOs are "trapped" into managing earnings upward even though the market correctly foresees this classic type of "signal jamming." Consistent with this, we present robust new empirical evidence that CEO age is a statistically and economically significant determinant of real activities and accruals-based earnings management levels. After numerous robustness tests to discriminate between our hypothesis and alternative explanations for the significance of CEO age, we conclude that implicit career stage incentives are important determinants of corporate earnings management. Our findings are consistent with executives' self-insights regarding their behavior, while also suggesting that CEO age may be a significant correlated omitted variable in prior academic earnings management studies.
\end{abstract}

JEL Classification: M40, M41.

Keywords: earnings management; career concerns; discretionary accruals; real activities management.

${ }^{*}$ We thank Ana Albuquerque, Bill Baber, Ken Euske, Jennifer Francis, Denis Gromb, Felix Höppe, Joe San Miguel, DJ Nanda, Marco Trombetta, Moqi Xu, Neng Wang, as well as seminar participants at Bocconi, Rotterdam School of Management at Erasmus University, the 6th Accounting Research Workshop in Bern, the AAA meetings in NYC, and the AAA-MAS conference in Seattle for helpful comments on earlier versions of this paper.

${ }^{\dagger}$ INSEAD, Boulevard de Constance, 77305 Fontainebleau, France. Email: liz.demers@insead.edu.

${ }^{\ddagger}$ Corresponding author. Graduate School of Business and Public Policy, Naval Postgraduate School, Monterey, CA 93943. Email: cwang@nps.edu. 


\section{Introduction}

Executives seem to face intense incentives to manage earnings, either in the form of accruals manipulations or by choosing real activities to attain an earnings benchmark. ${ }^{1}$ Most of the extant academic literature links these incentives for earnings management, directly or indirectly, to explicit contracts. ${ }^{2}$ While explicit contracting-based incentives clearly play an important role, the empirical archival literature to date has been almost silent on the effects of implicit contracts and implicit incentives over earnings management. ${ }^{3}$ However, a recent survey by Graham, Harvey and Rajgopal (2005) documents that more than three quarters of responding executives consider upward mobility in the labor market (i.e., an implicit career concerns based incentive) to be more important than short-run current compensation benefits in influencing their earnings management decisions. Our study addresses the apparent disconnect between this survey evidence regarding the importance of implicit contracts and the extant literature's focus on explicit contracting explanations for earnings management. We do so by investigating, both theoretically and using archival empirical data, the role of executive career concerns in the determination of corporate earnings management activities. We provide new and robust evidence that younger CEOs engage in less real activities and accruals-based income-increasing earnings management, even after controlling for explicit incentives and other factors that are known to be associated with earnings management. Our findings are consistent with executives' own self-insights and highlight the economically significant role played by CEOs' implicit career concerns in determining real activities and accruals based earnings management choices.

To motivate our empirical investigations, we first develop a model of earnings management that extends the seminal career concerns work of Holmstrom $(1982,1999)$ to incorporate features of the accrual accounting performance measurement system and the longer-term value-

\footnotetext{
${ }^{1}$ Some prominent examples of non-academic sources of attention to the issue of earnings management pressures include the famous speeches by Levitt (1998, 2003), as well as many articles from the popular press. An excellent and extensive academic summary is provided by Ronen and Yaari (2008).

${ }^{2}$ Contracting-based motives for earnings management that have been examined include executive current cash bonus maximization (Healy 1985), the avoidance of debt covenant violations (Defond and Jiambalvo 1994), more favorable equity pricing (Teoh, Welch and Wong 1998a and 1998b), political cost considerations (Key 1997), and executive equity compensation (Cheng and Warfield 2005).

${ }^{3}$ One exception is the study by Bowen, DuCharme and Shores (1995). These authors consider the impact of various stakeholders' implicit claims, notably excluding managerial career concerns, on accounting method choices (i.e., not accruals or real activities management perse). We discuss this related study in Section 2.
} 
destroying effects of real activities earnings management. The model consists of three distinct periods, when the manager is young (or early career stage), mature, and retired from the executive suite but available for board service. ${ }^{4}$ As a consequence of, alternatively, the reversing nature of accruals and the value destruction caused by real activities earnings management, our model leads to the surprising prediction (i.e., relative to Holmstrom $(1982,1999)$ and other career concerns models) that, in the absence of explicit compensation contracts, managers who maximize lifetime compensation in a perfectly competitive labor market would have little incentive to engage in income-increasing earnings management during the early stages of their careers and would face significant pressure to manage earnings upward in the mature period. The intuition for this result is that the executive receives only a fraction of the benefit of the managed earnings in the early stage of her career because some portion of the superior performance is attributed to noise or luck, whereas she is punished fully in the later years when the accruals reverse or the real activities manifest in value destruction. By contrast, at least some portion of the discretionary accruals (real activities choices) of the older executive will reverse (manifest in value destruction) after she has retired, and hence the benefits of earnings management exceed the costs for mature executives up to a certain optimal level. The model generates a "signal jamming" equilibrium (Stein (1989)) with efficient markets and inefficient managers; older executives engage in income-increasing earnings management in order to influence post-retirement (i.e., board service) labor market value. Although the labour market correctly foresees this opportunistic behavior and does not over-compensate managers in the post-retirement period, managers are nevertheless "trapped" into managing earnings in this way since any failure to do so will be punished by the market.

Using data from ExecuComp, we empirically test our theoretical model's prediction that early stage managers will engage in less income-increasing earnings manipulation than their older counterparts. With respect to accruals earnings management, we document that younger CEOs undertake less income-increasing accruals, by about $1 \%$ of total assets, than older CEOs.

\footnotetext{
${ }^{4}$ Throughout the text, we treat age and career stage as synonymous. Thus, we use the terms "mature," "older" and "more established," and respectively, "younger" and "earlier career stage," interchangeably. We draw a distinction between CEO age and tenure, however, which we investigate these as separate empirical measures as well.
} 
Also consistent with hypotheses, we find that younger managers undertake less income increasing real activities. Specifically, younger managers undertake less abnormal production costs, at the rate of about $1.7 \%$ of total assets, on average, and they incur greater abnormal discretionary expenses of about $2 \%$ of total assets, all relative to their older peers. Our results are robust across numerous specification checks, including the use of alternative age-based proxies for career stage, controlling for all other known determinants of discretionary accruals including numerous alternative proxies for explicit compensation- and stock-ownership-based wealth incentives, to alternatively dropping older executives and first-year executives from our sample, and to controlling for the effect of time-invariant firm and CEO characteristics that may be correlated with CEO age.

We extend our empirical analyses by investigating the behavior of younger executives who are faced with substantial incentives to manage earnings. For a sub-sample of firms that are close to missing analyst estimates, we find that younger managers seem to choose the "lesser of two evils" by managing accruals rather than undertaking real, potentially value-destroying actions to meet the earnings threshold. Specifically, we find that younger CEOs do not exhibit different propensities than their older counterparts with respect to accruals management when their firms are close to missing an earnings benchmark. By contrast, the younger executives do engage in less real activities management of about $3 \%$ to $4 \%$ of total assets, on average, relative to older CEOs who are within similar proximity to missing analyst expectations.

Our study contributes to both the career concerns and earnings management literatures. Recent studies in the career concerns area have documented that younger CEOs are more likely to undertake acquisitions (Matta and Beamish (2008); Yim (2010)) and that they are more likely to provide earnings forecasts (Dai et al (2009)). We document that CEO age affects another important aspect of corporate behaviour, the intensively debated and extensively studied accounting phenomenon of real and accruals based earnings management. We also contribute to the earnings management literature by providing both theoretical and empirical archival support for the survey-based results reported by Graham et al (2005) that career concerns are an important implicit incentive in driving earnings management choices. We show 
that younger executives have stronger disincentives to engage in income-increasing accrualsbased and real activities earnings management relative to their more established counterparts. Consistent with the earlier survey findings, our archival empirical results show that these implicit career based incentives are an important determinant of earnings management, over and above the explicit bonus- and equity-based incentives that have been the focus of the prior empirical accounting literature. Our findings of differential earnings management for young versus established CEOs are robust across many specifications, and they are economically significant for both real and accruals earnings management choices.

The remainder of the paper is organized as follows. Section 2 reviews the literature, develops a theoretical model, and generates our hypotheses. Section 3 describes our sample selection and data. Section 4 presents the empirical tests and Section 5 concludes.

\section{Literature Review, Model Development, and Hypotheses}

\subsection{Career Concerns: Extant Theoretical Models and Empirical Evidence}

Career concerns arise whenever the labor market uses the manager's current output to update its beliefs about the manager's ability, and then bases the manager's future wages upon these updated beliefs. Fama (1980) first discusses career concerns and proposes that explicit incentive contracts are not necessary to motivate managers since a manager can be disciplined through career concern based implicit incentives; better output links to better future managerial pay, while poor performance lowers the future labor market value of the manager. Holmstrom $(1982,1999)$ formally addresses the issue of implicit incentives in the early versus late stages of a manager's career. The Holmstrom $(1982,1999)$ model suggests that career concerns are greater for younger versus older managers; in the absence of contracts, managers work too hard in the early years of their careers (while the market is still assessing the manager's type) in order to influence the market's beliefs about their ability, and not hard enough in later years. Although in equilibrium the market is not fooled regarding the manager's type, the manager is nevertheless compelled to exert more effort in the early years of her career in 
order to avoid being negatively assessed. ${ }^{5}$

An extensive empirical literature examines various career concern predictions following from Holmstrom's career concerns model. For example, Gibbons and Murphy (1992) document that older CEOs' cash compensation is more sensitive to their firms' stock market performance, consistent with older executives being more motivated by explicit rather than implicit incentives in the years preceding retirement. Elsaid et al (2008) find that abnormal returns to $\mathrm{CEO}$ succession announcements are negatively related to the percentage of performance-based pay awarded to the newly hired (and presumed earlier career stage) CEOs, consistent with the notion that it is more efficient for earlier career stage CEOs to be paid in human capital increases from the managerial labor market rather than to have their current pay tied closely to performance. Brickley et al (1999) document that implicit performance incentives remain present even during the later years of executives' careers, as evidenced by pre-retirement accounting and stock market performance being important determinants of whether executives serve on their own or other boards after retirement. Matta and Beamish (2008) as well as Yim (2010) show that career concerns lead younger CEOs to undertake fewer corporate acquisitions, whereas Dai et al (2009) find that implicit incentives drive younger CEOs toward higher propensities for issuing earnings forecasts. Applying the career concerns model in a non-executive context, Chevalier and Ellison (1999) document that younger mutual fund managers face different implicit incentives relative to older managers since they are more likely to be fired for poor performance and for taking bold actions. Hong et al (2000) similarly document that, because of career concerns, younger stock analysts are much more likely to herd in their earnings forecasts.

More tightly linked to our setting, and a motivating factor for our study, is the descriptive evidence on career concern motivations for earnings management presented by Graham et al (2005). The authors survey more than 400 CFOs and document that over three quarters of the respondents report that upward mobility in the labor market matters more than short-run compensation in driving the desire to hit earnings benchmarks. Graham et al (2005) provide

\footnotetext{
${ }^{5}$ This notion of efficient markets with inefficient managers is known as a "signal jamming" equilibrium (see, e.g., Stein (1989)).
} 
evidence of an important disconnect in the earnings management literature in relation to executive compensation incentives for earnings management; while the survey evidence strongly suggests that implicit career concern incentives play the most important role in motivating earnings management, the existing earnings management literature typically links earnings management to explicit incentives such as contemporaneous cash bonuses and equity holdings.

One exception that we are aware of is a study by Bowen et al (1995) related to firm stakeholders' implicit claims on the firm's accounting method choice. The authors empirically document that proxies for the extent to which a firm depends upon the implicit claims of its customers, suppliers, employees, and short-term creditors are significant in explaining crosssectional variation in inventory and depreciation methods. Bowen et al (1995) thus provide initial evidence of the potential importance of implicit claims on the firm's reported earnings. Notably, however the authors do not specifically examine either CEO career concerns as an implicit motivation for earnings management nor do they examine the impact of implicit claims on discretionary accruals or real activity choices, which are the focus of the current study.

\subsection{A Model of Earnings Management Based Upon Career Concerns}

\subsubsection{Model Setup and Assumptions}

We develop a model of earnings management based upon managerial career concerns by building on the seminal work of Holmstrom $(1982,1999)$. To illustrate the effects of career concerns we adopt the simplest possible three-period setting, in which the manager is young, established, and retired. In periods 1 and 2, the executive is responsible for managing the firm, while in period 3 the manager may serve as a board member during retirement. The labor market is assumed to be competitive, and the manager is paid, at the beginning of each period, the expected output that she will deliver in the current period given her history of outputs. ${ }^{6}$

Let $\eta$ denote the manager's unobservable productivity. For simplicity, assume that $\eta$

\footnotetext{
${ }^{6}$ As in other career concerns models, we do not consider optimal dynamic contracting, a significantly more difficult problem.
} 
remains constant over time, with the following prior distribution

$$
\eta \sim \mathcal{N}\left(m_{0}, 1 / h_{0}\right)
$$

where $h_{0}$ is the precision of the prior, the inverse of its variance.

Let $x_{t}$ denote the reported output in period $t$ (i.e., $x_{1}$ and $x_{2}$ are the earnings reported by the manager when she is young and established respectively, while $x_{3}$ is the value added from the manager's post-retirement board service). During periods $t=1,2$ the manager may manipulate accruals or engage in real activities to manage earnings. The period 1 reported earnings are therefore given by

$$
x_{1}=\eta+\alpha_{1}+\epsilon_{1}
$$

where $\alpha_{1}$ is the earnings management through accruals manipulation or real activities in period 1. $\epsilon_{1}$ is the shock, which is uncorrelated with the manager's productivity $\eta$. Shocks in each period are assumed to be normally distributed with precision $h_{\epsilon}$, such that

$$
\epsilon_{t} \sim \mathcal{N}\left(0,1 / h_{\epsilon}\right)
$$

We assume that $\eta, \epsilon_{1}, \epsilon_{2}$ and $\epsilon_{3}$ are jointly independent.

In period 1, when the manager is young, it is apparent that she can "impress" the labor market in the short term by boosting earnings via accruals manipulation or real activity choices. However, the amount of accruals manipulation in period 1 must be fully reversed in period 2. ${ }^{7}$ Moreover, since real activity earnings management involves a deviation of real activities from the optimal level, which is to say that these activities are value-destroying, real activity alterations in period 1 are penalized at a multiple rate in period $2 .^{8}$ In other words, we

\footnotetext{
${ }^{7}$ This assumption states that earnings cannot be indefinitely managed upward via accruals without triggering a forced earnings restatement or fraud investigation, both of which are assumed to be associated with extreme penalties to the manager. In other words, the manager needs to balance the books via accruals reversals "eventually." Since the manager only works for two periods in our model, full reversal in period 2 of the period 1 earnings manipulation is the natural assumption.

${ }^{8}$ In contrast to accrual earnings management, which occurs when management manipulates reported earnings by exploiting the discretion allowed under GAAP to intertemporally shift earnings, real activities management involves managers taking actions to adjust the timing and/or scale of the firm's underlying business activities. Thus, a key distinction between accruals-based and real activities earnings management is that the latter
} 
assume that accruals reversal is dollar-for-dollar while the real activity earnings management reversal is more than dollar-for-dollar.

In period 2, when the manager is at the established stage of her career, the period 1 earnings manipulations (accruals or real activities) are reversed and the manager has the option to engage in a second round of earnings manipulations. Let $\alpha_{2}$ denote the amount of "new" earnings manipulation in period 2. Reported output in period 2 is given by

$$
x_{2}=\eta+\alpha_{2}-\lambda \alpha_{1}+\epsilon_{2},
$$

where $\lambda=1$ if the channel of earnings management is accruals based, and $\lambda>1$ if earnings management is accomplished via real activities.

The second period's earnings manipulations also reverse in the subsequent period, after the manager is retired. Because the period 2 manipulations will reverse only when the firm is under new management, however, the retired manager will bear no "direct" consequences from her period 2 earnings manipulation. When inferring the manager's productivity (i.e., her type), the market will not incorporate the third period earnings reversal. Therefore, the only mitigating force for our manager not to engage in excess manipulation in period 2 is the convex cost of manipulating earnings. ${ }^{9}$ Let $c(\alpha)$ denote the cost associated with earnings manipulation, with the standard properties of $c^{\prime}(\alpha)>0, c^{\prime \prime}(\alpha)>0$, and $c^{\prime}(0)=0$.

Lastly, the retirement period 3 output, $x_{3}$, is given by

$$
x_{3}=\eta+\epsilon_{3}
$$

Let $w_{t}$ denote the executive's wage in period $t$, paid at the beginning of the period. Under the assumption of competitive labor markets and no explicit performance-based pay, we have

$$
w_{1}=\mathbb{E}\left(x_{1} \mid \text { prior }\right)
$$

destroys corporate value whereas the former simply shifts earnings across periods.

${ }^{9}$ Liang (2004) discusses these costs at greater length. 


$$
\begin{gathered}
w_{2}\left(x_{1}\right)=\mathbb{E}\left(x_{2} \mid x_{1}\right), \\
w_{3}\left(x_{1}, x_{2}\right)=\mathbb{E}\left(x_{3} \mid x_{1}, x_{2}\right) .
\end{gathered}
$$

\subsubsection{Optimal Earnings Management}

The executive's objective is to maximize her utility function, which is represented as the discounted present value of her lifetime compensation, net of the cost of earnings management:

$$
U=\mathbb{E}\left[w_{1}-c\left(\alpha_{1}\right)+\beta\left(w_{2}-c\left(\alpha_{2}\right)\right)+\beta^{2} w_{3}\right]
$$

where $0<\beta<1$ is the executive's subjective discount rate.

Substituting (5) into (8) yields:

$$
w_{3}\left(x_{1}, x_{2}\right)=\mathbb{E}\left(\eta \mid x_{1}, x_{2}\right)
$$

Let $\bar{\alpha}_{1}$ and $\bar{\alpha}_{2}$ denote the labor market's conjectures of $\alpha_{1}$ and $\alpha_{2}$, respectively. $z_{1}$ and $z_{2}$ represent the market's conjectures of unmanaged earnings, defined as:

$$
\begin{gathered}
z_{1} \equiv x_{1}-\bar{\alpha}_{1}=\eta+\epsilon_{1} \\
z_{2} \equiv x_{2}-\bar{\alpha}_{2}+\lambda \bar{\alpha}_{1}=\eta+\epsilon_{2} .
\end{gathered}
$$

We apply the standard belief updating formula to obtain the conditional distribution of $\eta$ given $z_{1}$ and $z_{2}$ as follows: $:^{10}$

$$
\eta \mid\left(z_{1}, z_{2}\right) \sim \mathcal{N}\left(m_{0}+\frac{h_{\epsilon}}{h_{0}+2 h_{\epsilon}}\left(z_{1}+z_{2}-2 m_{0}\right), \frac{1}{h_{0}+2 h_{\epsilon}}\right) .
$$

Thus, the market begins with prior $m_{0}$, and adjusts its beliefs about $\eta$ based upon the information conveyed by $z_{1}$ and $z_{2}$. Similar to Holmstrom $(1982,1999)$, the market correctly anticipates the level of earnings management in equilibrium. Therefore, $z_{1}$ and $z_{2}$ are known

\footnotetext{
${ }^{10}$ See, e.g., Greene (1997) Theorem 3.6 on marginal and conditional normal distributions.
} 
in equilibrium given the observed outputs in periods 1 and $2, x_{1}$ and $x_{2}$, respectively.

The wages are given by:

$$
\begin{gathered}
w_{3}\left(x_{1}, x_{2}\right)=\mathbb{E}\left(\eta \mid x_{1}, x_{2}\right)=m_{0}+\frac{h_{\epsilon}}{h_{0}+2 h_{\epsilon}}\left(x_{1}+x_{2}-\bar{\alpha}_{2}+(\lambda-1) \bar{\alpha}_{1}-2 m_{0}\right) \\
w_{2}\left(x_{1}\right)=\mathbb{E}\left(\eta \mid x_{1}\right)^{11}+\alpha_{2}^{* 12}-\lambda \alpha_{1}=\frac{h_{0} m_{0}+h_{\epsilon}\left(x_{1}-\bar{\alpha}_{1}\right)}{h_{0}+h_{\epsilon}}+\alpha_{2}^{*}-\lambda \alpha_{1} \\
w_{1}=\mathbb{E}\left(x_{1} \mid \text { prior }\right)=\mathbb{E}(\eta \mid \text { prior })+\bar{\alpha}_{1}=m_{0}+\alpha_{1}^{*} .
\end{gathered}
$$

Backward induction in a perfect Bayesian equilibrium immediately implies the following first order conditions for period 2, where we choose $\alpha_{2}$ to maximize (9) using (14):

$$
\frac{\partial U}{\partial \alpha_{2}}=-\beta c^{\prime}\left(\alpha_{2}\right)+\beta^{2} \frac{h_{\epsilon}}{h_{0}+2 h_{\epsilon}}=0
$$

which in turn implies the closed form solution:

$$
c^{\prime}\left(\alpha_{2}^{*}\right)=\beta \frac{h_{\epsilon}}{h_{0}+2 h_{\epsilon}}
$$

The first order derivative with respect to $\alpha_{1}$ is:

$$
\frac{\partial U}{\partial \alpha_{1}}=-c^{\prime}\left(\alpha_{1}\right)+\beta\left(\frac{h_{\epsilon}}{h_{0}+h_{\epsilon}}-\lambda\right)+\beta^{2} \frac{h_{\epsilon}}{h_{0}+2 h_{\epsilon}}(1-\lambda)
$$

Since this derivative is negative, we end up with the corner solution $\alpha_{1}^{*}=0$ which immediately implies that $w_{1}^{*}=m_{0}$. We therefore have the result that the manager engages in zero manipulation (accruals or real activities) in period 1 when she is young (i.e., $\alpha_{1}^{*}=0$ ), but that she does engage in income-increasing earnings manipulation in period 2 when she is established (i.e., $\alpha_{2}^{*}>0$ ).

\footnotetext{
${ }^{11}$ We obtain $\mathbb{E}\left(\eta \mid x_{1}\right)$ by once again using the standard belief updating formula.

${ }^{12}$ Here we use the fact that both the market and the manager are able to figure out the optimal $\alpha_{2}^{*}$ by solving the backward induction problem in a perfect Bayesian equilibrium, as specified in (17) and (18).
} 


\subsubsection{Discussion of the Model}

A number of key observations from our model merit being pointed out. The first two issues derive from assumptions that are fundamental to career concerns models in general rather than being specific to our particular earnings management setting. First, career concerns models assume that both the market and the manager are equally informed about managerial ability in all periods. All participants learn about the manager's type in the same way, and there is no information asymmetry. In other words, these are not adverse selection models. The manager does try to influence the market's inference about her type, and consequently a moral hazard issue will arise. In equilibrium, however, no one is fooled.

Second, recall that the wages paid to the executive are assumed to be determined at the beginning of each period based upon expected output. As a consequence of this feature, the model effectively assumes away the role of explicit compensation contracts, where the latter entail compensation being paid at the end of the period based upon realized output. Accordingly, all of the model's predictions derive solely from implicit incentives and implicit contracts. This point is fundamental to our study, and should clarify the notion that career concerns models are fundamentally different from a manager's horizon problem. As the most authoritative studies on the subject make clear, the "horizon problem" is inextricably linked to explicit contracts and incentives. ${ }^{13}$ By contrast, such explicit incentives are totally absent from our model; the incentives in our model are entirely implicit. Alternatively stated, a manager with a horizons problem is apt to state that he "could care less about the future" (because he will have left the firm and the labor force), whereas a manager with career concerns has the opposite mentality; he cares very much about the future and his career prospects.

\footnotetext{
${ }^{13}$ For example, Smith and Watts (1982, p. 146) first describe the horizon problem in relation to bonus compensation as follows, "Bonus plans can affect the real investment and financing decisions of the firm. For example, because they are typically tied to annual profits, bonus plans give managers incentives to turn down positive NPV projects with long pay back and to take negative value projects that impose expenses only after the manager retires." Similarly, Dechow and Sloan (1991) empirically investigate the horizon problem by testing the hypothesis that earnings-based performance measures provide executives with incentives to focus on short-term performance. In terms of its academic study, the "horizon problem" also tends to be linked to opportunistic behavior in altering optimal real activity (such as cutting R\&D), rather than being associated with accruals manipulation. One exception is the recent study of Kalyta (2009), who finds evidence consistent with his hypothesis that CEOs whose pensions are based upon pre-retirement firm performance are more likely to manage earnings upwards using discretionary accruals.
} 
The final commentary to be made on our model relates to the economic intuition behind its predictions, which are particular to our setting. Specifically, the predictions of our career concerns model are being driven alternatively by the closed-ended, reversing nature of the accrual accounting system and the value-destroying effects of real earnings management. The intuition is that, for each dollar of earnings management in the first period, the impact on the executive's second period wage is $\frac{h_{\epsilon}}{h_{0}+h_{\epsilon}}$, which is less than one dollar. In other words, there is a "leakage" that the executive does not capture as a result of the noise in the system such that younger managers only receive a fraction of the benefit of the first period's managed earnings in their second period wage because some of the earnings-management-induced aboveexpectations performance is attributed to noise or luck. By contrast, the manager's second period wage is penalized at least dollar-for-dollar of the amount of earnings management (i.e., $\lambda \geq 1$ ). Furthermore, in the case of real earnings management, any period 1 manipulation will have a negative impact on $w_{3}$ via lower $\left(x_{1}+x_{2}\right) \cdot{ }^{14}$ Finally, with reference to equation (19), and driven by the assumption in our model that accruals manipulations are value-neutral $(\lambda=1)$ while real activities management are value-destroying $(\lambda>1)$, we observe that the disutility associated with one unit of accruals earnings management is lower than the disutility stemming from one unit of real activities earnings management. This observation suggests that, everything else being equal, accruals manipulation is the "lesser of two evils" for a younger executive.

In summary, the manager's utility is maximized by taking zero income-increasing accruals or real activities earnings management choices when she is young and some positive amount of income-increasing earnings management when she is established. There is greater disutility associated with real activities earnings management relative to accruals manipulations. The mature executive's earnings management activities do not reverse during her tenure and the market fully expects the older executive to choose the optimal level of earnings management (i.e., subject to a cost-benefit analysis) so as to influence her post-retirement board service compensation. Consistent with other career concerns models, in equilibrium the market is not fooled about the manager's choice of earnings management. Rather, the market correctly con-

\footnotetext{
${ }^{14}$ This result is evident from the third term in equation (19), which is negative for $\lambda>1$ but zero for $\lambda=1$.
} 
jectures the amount of earnings management in period 2 and appropriately adjusts downward the third period wage such that the executive is not overpaid. The manager is nevertheless trapped into introducing income-increasing earnings management in the second period since any failure to do so will drive the market valuation against her. This equilibrium deviates from the first-best solution in a manner similar to Stein (1989). ${ }^{15}$

\subsection{Career Concerns and Earnings Management Empirical Hypotheses}

\subsubsection{Career Concerns and Discretionary Accruals}

The theoretical model developed in the previous section involves an executive who is either young or established during her active (i.e., pre-retirement) career, and accruals that reverse entirely in the period subsequent to when they were initially taken. Although this is clearly a simplified representation of the executive setting, the model's empirical prediction is robust to relaxing the condition related to the accruals reversals. The key assumption is that accruals manipulations undertaken in the earlier career stage are more likely to reverse during the executive's tenure than the accruals that she manages at the later stages of her career. ${ }^{16}$ Following the model's predictions, but recognizing that the practical world involves additional incentives that are not explicitly specified in our necessarily simplified formal representation, ${ }^{17}$ we test the following empirical hypothesis:

H1: Ceteris paribus, younger managers use less income-increasing discretionary accruals than their older counterparts.

\footnotetext{
${ }^{15}$ In a related context, but addressing a different research question and using a different model set-up, Stein (1989) demonstrates that a manager concerned about "short-run" stock prices will behave myopically in order to boost current earnings so as to mislead the market. In equilibrium, the market is not fooled by this signal jamming but managers are nevertheless "trapped" into behaving myopically, similar to the Nash equilibrium in the classical prisoner's dilemma game.

${ }^{16}$ Consistent with this, Bhoraj et al (2009) document that firms that manage earnings to meet or beat analyst forecasts exhibit short-run price benefits but then tend to underperform over longer horizons. They further provide evidence that managers seem to understand the myopic nature of their actions, consistent with the implicit understanding that we endow to the managers in our setting.

${ }^{17}$ For example, explicit bonus contracts and/or capital markets consequences of reporting earnings that fall below expectations may motivate managers to do some accrual earnings management even in the earlier stages of their careers. Accordingly, our empirical prediction is that younger managers will use less, but not necessarily zero, income-increasing discretionary accruals, on average.
} 


\subsubsection{Career Concerns and Real Activities Earnings Management}

Most of the early empirical research related to real activities management considers the opportunistic reduction of $\mathrm{R} \& \mathrm{D}$ spending in order to achieve earnings targets (e.g., Baber et al (1991), Dechow and Sloan (1991), Bushee (1998), and Bens et al (2002)). ${ }^{18}$ Other empirical studies related to real operational activities management investigate firms' opportunistic propensities to dip into LIFO layers (Dhaliwal et al (1994)), cut sales prices (Jackson and Wilcox (2000)), or sell long-term assets and marketable securities (Bartov (1993), Black et al (1998), Hermann et al (2003), and Gunny (2005)) to meet earnings benchmarks. ${ }^{19}$ Roychowdhury (2006) extends this literature by focusing on three significant operational activities through which earnings can be managed, including: 1) acceleration of sales through limited time price discounts or more favorable credit terms (e.g., zero-interest financing); 2) excessive production to reduce cost of goods sold by inventorying part of the overhead; and 3) decreases of discretionary expenses. ${ }^{20}$

Our hypothesis related to real activities management derives from the theoretical model combined with a similar logic to that used above in the case of accruals, and is stated as follows:

H2: Ceteris paribus, younger managers use less real activity earnings management than their older counterparts.

In their study of real earnings management in the context of career horizon concerns, Dechow and Sloan (1991) document that CEOs reduce discretionary expenditures, such as $\mathrm{R} \& \mathrm{D}$ and advertising, in their last years in office in order to boost earnings and maximize cash

\footnotetext{
${ }^{18}$ In a related theoretical study, Baber (1985) models the relation between managerial discretionary spending and explicit budget-based compensation. He shows that if a lump-sum bonus is paid for meeting budgets, then managers prefer more discretionary expenditures when budgets are tight. Baber (1985) does not consider implicit career stage incentives, but rather models the explicit bonus-based compensation incentives over discretionary expenses that are expected to yield an uncertain future payoff.

${ }^{19} \mathrm{See} \mathrm{Xu}$ et al (2007) for an extensive review of the real earnings management literature.

${ }^{20}$ Real financing activities have also been documented to be a means used to achieve earnings-related reporting objectives. Such financing-type transactions include debt-equity swaps (Hand (1989)) and in-substance defeasance transactions (Hand et al (1990)), debt structurings (Marquardt and Weidman (2005)), share buybacks (Bens et al (2003), Hribar et al (2006)), and stock-for-stock mergers that enable firms to use the earningsadvantageous pooling of interests method (Ayers et al (2002)). Large financing transactions are often only undertaken with the approval of the board of directors and hence are not investigated in the context of our CEO career stage hypotheses.
} 
bonuses. While their results are consistent with our $H 2$, their hypothesized reason for this finding is quite different. While Dechow and Sloan (1991) conjecture that the documented cuts in discretionary expenditures derive from the explicit incentives of compensation contracts, we investigate whether real activities management is undertaken in response to implicit incentives. Our empirical tests, discussed further below, are designed to identify the incremental effects of implicit incentives due to age (our empirical proxy for career stage) over the explicit incentives of pay-for-performance compensation documented to be relevant for earnings management by Dechow and Sloan (1991) and other prior studies.

\subsection{Early Career Stage Earnings Management Trade-Offs}

It has been well documented that there are strong capital markets pressures for managers to meet earnings benchmarks, particularly in the U.S. (Burgstahler and Dichev (1997); Degeorge, Patel, and Zeckhauser (1999); Skinner and Sloan (2002); amongst many others) and that the capital markets reward firms for meeting analysts' earnings forecasts (Bartov, Givoly, and Hayn (2002); Kasnik and McNichols (2002); among others). Accordingly, even though our model suggests that early career stage managers should generally be reluctant to manage earnings upwards, we nevertheless expect that even younger executives will be driven to manage earnings under extreme circumstances, such as when their firm is close to missing analysts' consensus earnings forecasts. ${ }^{21}$ Thus we investigate younger managers' propensities to manage accruals and real activities, respectively, relative to their older counterparts in such high earnings pressure situations. ${ }^{22}$ Following from our model, which posits that the disutility from real activities earnings management exceeds that from intertemporal income shifting via

\footnotetext{
${ }^{21}$ Reporting a loss or earnings that are less than the prior year's same quarter earnings per share are also considered to be important earnings benchmarks that may induce earnings management, however the evidence suggests that meeting (or beating) analysts' estimates is the single most compelling earnings target (Brown and Caylor (2005)) and accordingly we focus on this benchmark in our primary career concerns based earnings management tests.

${ }^{22}$ Durtschi and Easton (2005) suggest that the discontinuity in analyst forecast errors around zero does not provide ipso facto evidence of earnings management. If one were to believe their interpretation of the data, then this would imply that some of the firms that we and prior researchers consider to be earnings management "suspects" may not actually have greater propensities to manage earnings. Similarly, Payne and Thomas (2003) claim that ex post I/B/E/S adjustments for stock splits may lead some firms to appear as having just beat analyst estimates, whereas at the time of reporting the forecast error was greater than a penny. Any such misclassifications of firms that were not more likely to have managed earnings into our "suspects" sample works against our finding evidence of differential behavior within the suspected set of firms.
} 
accruals manipulation, ceteris paribus, we hypothesize the following:

H3A: When their firm is close to missing an earnings target, younger managers, like their more established peers, feel pressured to manage accruals in order to meet the analysts' benchmark.

HзВ: When their firm is close to missing an earnings target, younger managers are less likely than their more established peers to undertake real earnings activities in order to meet the analysts' benchmark.

Taken together, evidence in support of both Hypotheses 3A and 3B is consistent with the notion that younger managers choose the "lesser of two evils" (i.e., accruals over real activities management) when pressured by the capital and/or labor markets to manage earnings to meet analyst benchmarks.

\section{Sample Selection and Data Description}

\subsection{Data Sources and Sample Selection Process}

All of the data used in our study are derived from public sources. We obtain financial statement data from Compustat and stock market metrics from the CRSP database. For a subset of our tests, we rely upon analyst forecast estimates derived from I/B/E/S. Data related to executives' compensation, age, tenure with their firm, and stock and option holdings are derived from the ExecuComp database.

We restrict our sample to CEOs rather than other, lower level executives (e.g., CFOs) for several reasons. First, although the CFO is presumably actively involved in the firm's accounting and financial reporting process (and thus in the determination of abnormal accruals), the CEO has the ultimate authority over the firm's management (including, e.g., decisions regarding real activities) as well as its financial reporting. Second, focusing on any other single executive position such as the CFO substantially reduces the sample size due to the more restricted ExecuComp coverage of non-CEO executives' income, ownership, and age data. Finally, focusing on CEOs enables us to relate our findings to an extensive prior literature related to these executives. 
The sample selection is summarized in Table 1 . We begin our sample selection with the intersection of the ExecuComp database with the Compustat annual industrial and research files for the period of 1992 (the inception of ExecuComp data) through 2006. We exclude financial firms and REITs (SIC codes 6000-6999) and all firm-year observations for which sales or total assets are negative. In order to be included in the sample, we require each firmyear observation to have at least eight Compustat observations available from the same 2-digit SIC industry-year so that we can estimate the earnings accrual and real activities management models described below. Excluding observations missing data required to estimate the modified Jones accrual model and/or the abnormal expense models (discussed below) leaves 18,247 firmyear observations (2,148 unique firms, 4,196 unique CEOs) for our primary sample.

\subsection{Descriptive Statistics}

Panel A of Table 2 provides descriptive statistics for the sample firms used in our primary hypotheses tests. Detailed definitions of these variables are provided in the Appendix. Untabulated results reveal that our sample contains firms that are, on average, larger (in terms of sales, market capitalization, and total assets), than the mean firm from the CRSP-Compustat universe. In this respect, our study suffers the same large firm bias that is known to affect all research that is subject to the ExecuComp data availability constraint. Relative to the non-financial firm CRSP-Compustat universe, sample firms are significantly more leveraged, but have approximately the same book-to-market ratios. Virtually all are audited by one of the Big-5 auditors. Mean and median CEO age is 56 years; their bonuses account for approximately $22 \%$ of compensation, on average, and option and stock holdings represent a small fraction of the shares outstanding. Implicit claim, $N O A_{t-1}$, Litigation, and the SOX dummy variable, all of which are defined in detail in the Appendix, are factors that prior studies have documented to be associated with earnings management behavior. We therefore include these variables as controls in our multivariate tests. 


\subsubsection{Capturing Career Stage}

We view the CEO's age as best capturing his career stage, and thus our first empirical proxy for career stage is simply the CEO's age, measured as a continuous variable. We also consider that there may be a non-linear relation between earnings management and career stage, and thus we develop a second age-based proxy for career stage using an indicator variable, young, that is set equal to one for CEOs whose age is less than 56, the median age for the sample, and zero otherwise.

An alternative perspective is to examine the CEO's tenure with the firm in the context of career stage. Although we recognize the potential importance of CEO tenure on executive decisions (e.g., Dikoli et al (2009)), in our view this measure captures less well the underlying constuct of interest in our study. ${ }^{23}$ In untabulated results we nevertheless separately include a variable capturing the CEO's tenure in the top post, measured as the difference between the observation year and the year that the CEO became the CEO of his/her current firm. With the inclusion of the tenure variable, the coefficients on our age and young indicator test variables of interest retain their signs, magnitudes, and significance levels across all of the regression permutations discussed below. By contrast, the tenure variable is only significant in one of the abnormal discretionary expense regressions.

\subsection{The Estimation of Discretionary Accruals}

We use the entire Compustat universe to estimate discretionary accruals for each of our firmyear observations. For each 2-digit SIC industry-year with at least 8 observations, we model total accruals using the cross-sectional modified Jones model (Dechow et al (1995)) as follows:

$$
T A_{j, t}=\alpha_{1}\left(1 / A_{j, t-1}\right)+\alpha_{2}\left(\Delta R E V_{j, t}-\Delta R E C_{j, t}\right)+\alpha_{3} P P E_{j, t}+\epsilon_{j, t}
$$

\footnotetext{
${ }^{23}$ For example, an otherwise "young" CEO of, say, 50 years of age with 10 years of tenure in the top post nevertheless has, in expectation, many years left in her career. Accordingly, we would expect this CEO to take less income-increasing accruals or real decisions because, in expectation, these will reverse before she retires. By contrast, a 63-year-old CEO with 3 years of tenure with his firm is expected to engage in more income-increasing earnings management activities because it is more likely that he will be retired by the time the repercussions of his actions are recognized by the firm (i.e., in the form of accruals reversals or value destruction).
} 
where $T A_{j, t}=E B X_{j, t}-C F O_{j, t}$, with $E B X$ being earnings before extraordinary items and discontinued operations (Compustat data123) and $C F O$ being the operating cash flow from continuing operations (Compustat data308 minus data124). $A_{j, t-1}$ is the prior period's total assets (Compustat data6), and each of $T A_{j, t}$ (total accruals), $\Delta R E V_{j, t}$ (change in sales, Compustat data12), $\triangle R E C_{j, t}$ (change in net receivables, Compustat data2) and $P P E_{j, t}$ (gross PP\&E, Compustat data7) are all scaled by this lagged total assets measure.

Estimation of equation (20) produces industry-year specific coefficients that in turn yield fitted values and residuals for each firm-year observation included in our sample. Following the extensive prior literature, we interpret the fitted values from these regressions to be normal accruals and the residuals to be the discretionary accruals metrics that will be used in the formal hypothesis tests. As reported in Table 2B, these procedures yield mean (median) discretionary accruals of $0.016(0.001)$, and there is a considerable amount of cross-sectional variation in this variable. Estimated discretionary accruals for the firms in our sample are broadly comparable to those of prior studies such as Cheng and Warfield (2005) and Cohen, Dey and Lys (2008) who use the same methodology.

\subsubsection{Alternative Measures of Discretionary Accruals}

Although our primary tabled results discussed below use the same measure of discretionary accruals as adopted by Cheng and Warfield (2005) and Cohen et al (2008), we nevertheless run several robustness checks using alternative estimates of discretionary accruals. First, we use the modified Jones model applied to the Fama-French (1997) industry classifications instead of those based upon 2-digit SIC codes. Second, we use the performance-matching technique proposed by Kothari, Leone and Wasley (2005). In untabulated results, we find that all of the hypothesis test results reported below are robust to either of these two alternative measures of discretionary accruals, and often the results are slightly stronger. ${ }^{24}$

\footnotetext{
${ }^{24}$ Detailed results are available from the authors upon request.
} 


\subsection{The Estimation of Real Activities Management}

Roychowdhury (2006) uses three empirical measures to detect real activities manipulation, including abnormal cash flows from operations, abnormal production costs, and abnormal discretionary expenses. Given the primacy of earnings in CEO performance evaluation, compensation, and retention decisions, we focus on the two real activities measures developed by Roychowdhury (2006) that are most directly tied to earnings and that have unambiguous performance measurement implications, abnormal production costs and abnormal discretionary expenses. Price discounts, more favorable credit terms, and overproduction all induce ab-

normally high production costs relative to sales. Following from Hypothesis 2, we therefore expect that abnormal production costs bear a positive association with managerial age. Cutting discretionary expenses such as $\mathrm{R} \& \mathrm{D}$ and advertising leads to abnormally low discretionary expenses, and therefore Hypothesis 2 leads us to expect that younger managers will be associated with higher abnormal discretionary expenses.

Following the methodology developed by Roychowdhury (2006), we estimate the following two cross-sectional regressions for each industry-year:

$$
\frac{\operatorname{Prod}_{j, t}}{A_{j, t-1}}=\beta_{1} \frac{1}{A_{j, t-1}}+\beta_{2} \frac{\text { Sales }_{j, t}}{A_{j, t-1}}+\beta_{3} \frac{\Delta \text { Sales }_{j, t}}{A_{j, t-1}}+\beta_{4} \frac{\Delta \text { Sales }_{j, t-1}}{A_{j, t-1}}+\epsilon_{j, t}
$$

where $\operatorname{Prod}_{j, t}=$ COGS (Compustat data41) $+\Delta I N V$ (Compustat data3), Sales S $_{j, t}(\mathrm{Com}-$ pustat data12) is the current year's sales, $\Delta$ Sales $_{j, t}$ is the current year's change in sales, $\Delta$ Sales $_{j, t-1}$ is last year's change in sales, and $A_{j, t-1}$ is the lagged value of total assets, and

$$
\frac{\operatorname{DisExp}_{j, t}}{A_{j, t-1}}=\gamma_{1} \frac{1}{A_{j, t-1}}+\gamma_{2} \frac{\text { Sales }_{j, t-1}}{A_{j, t-1}}+\epsilon_{j, t}
$$

where DisExp $p_{j, t}$ is the sum of advertising expense (Compustat data45), R\&D (Compustat data46) and SG\&A (Compustat data189), and the other variables are as previously defined.

The coefficients derived from industry-year estimations of (21) and (22) produce fitted values for each firm-year which correspond to normal production costs and normal discretionary expenses, respectively, and the residuals from each of these two models provide measures 
of abnormal production costs and abnormal discretionary expenses, respectively. Summary statistics for each of these measures are presented in Table 2B. As shown, the mean abnormal production costs and average abnormal discretionary expenses are approximately $7 \%$ of total assets, which are broadly comparable to the estimates reported by Cohen et al (2008). ${ }^{25}$

\subsection{Estimation of Explicit Earnings Management Incentives}

Although explicit incentives do not play a role in our theoretical model, multivariate empirical tests of the career stage hypothesis must necessarily control for CEOs' explicit earnings management incentives in order to avoid a possible correlated omitted variables bias. As no single generally accepted empirical proxy for this construct exists, we estimate multiple specifications that include alternative "state-of-the-art" measures for the CEOs' explicit wealth- and compensation-based earnings management incentives. The general predictions from theory and prior empirical literature are that higher levels of cash bonus (or performance-based-pay otherwise determined) lead to higher levels of income-increasing earnings management as managers have incentives to push the envelope in order to meet performance pay thresholds. By contrast, CEO stock and option ownership lead to longer-term managerial perspectives and thus are predicted to be associated with lower levels of short-term-oriented earnings management.

Our first measure of an explicit compensation-based incentive for earnings management is captured by the percentage of CEO pay derived from cash bonus compensation (see, Cheng and Warfield (2005), amongst many other studies that have adopted a similar measure). As a second alternative, we use the CEO's compensation-earnings coefficient suggested by Bushman, Engel, and Smith (2006). We measure separately the CEO's wealth-based incentives using several alternative proxies. First, we include the CEOs' percentage ownership of the company via equity and option holdings, respectively (Cheng and Warfield (2005) and Cohen et al (2008)). Second, we use the composite wealth-based incentive measure proposed by Bergstresser and Philippon (2006) to capture in a single variable the combined stock- and options-based CEO incentives over earnings. Estimations of the Bushman et al (2006) and

\footnotetext{
${ }^{25}$ Roychowdhury (2006) does not report descriptive statistics for his estimates of abnormal discretionary expenses and production costs.
} 
Bergresser and Philippon (2006) measures are each described below.

\subsubsection{Pay-Earnings Sensitivity Measure}

We develop a measure of the CEO's pay-earnings sensitivity by adopting the regression-based compensation-earnings coefficient ("CEC") metric suggested by Bushman, Engel and Smith (2006, equation 3), which is as follows:

$$
C O M P_{t}=\alpha+C E C * \Delta E A R N_{t}+C R C * R E T_{t}+\varepsilon_{t}
$$

where $C O M P_{t}$ is the percentage change in the CEO's cash compensation in year $t ; \Delta E A R N_{t}$ is the change in earnings before extraordinary items and discontinued operations between year $t$ and year $t-1$, deflated by the total assets at the beginning of year $t ; R E T_{t}$ is the firm's cumulative stock market return over the 12-month period of the firm's fiscal year $t$; CEC is the compensation-earnings coefficient; and CRC is the compensation returns coefficient. We estimate the regression represented by equation (23) on a firm-specific basis, and we adopt the estimated CECs as a measure of the CEOs' explicit earnings-based incentives over earnings management activities, which we refer to as the pay-earnings sensitivity parameter. ${ }^{26}$ Descriptive statistics related to the estimated firm-specific pay-earnings sensitivity coefficients to be used as control variables in our subsequent tests are provided in Table $2 \mathrm{~A}$. The mean and median of our estimates are broadly similar, albeit somewhat larger, than those reported

\footnotetext{
${ }^{26}$ Although Bushman et al (2006) require 20 observations per firm in order to compute their CEC estimates, they use compensation data gathered from the Forbes annual survey and thus have a much longer potential time series to work with than that which is available to us from the ExecuComp database. We require only 3 years of data to obtain our CEC estimates. As Bushman et al (2006) recognize, the timeseries specification imposes assumptions related to the stationarity of the relationship between pay and performance that are more likely to be violated as the length of the timeseries is extended. Our research design choice maximizes the number of observations available for the second stage test regressions of interest in our study and imposes lighter stationarity assumptions on the CEC estimates, but at the potential expense of greater measurement error being embedded in the CEC estimates. Because the pay-sensitivity estimates are merely control rather than test variables in our second stage regressions of interest, and also given that we report specifications using alternative proxies for the same construct, we are willing to accept this measurement error trade-off. To eliminate the effects of any extreme outliers arising from this process, however, we winsorize the top and bottom $1 \%$ of the CEC estimates. As a further specification check, we again follow Bushman et al (2006) and alternatively measure the $\mathrm{CEC}$ at the two-digit industry level, requiring a minimum of 20 observations per industry, and including year fixed effects in the regressions. All of the results from the second stage analyses related to our age-based test variables of interest as reported below are robust to the inclusion of this alternative industry-based pay-sensitivity measure.
} 
by Bushman et al (2006), the distribution of our estimates is wider, and we have a slightly higher percentage of negative-valued estimates relative to the prior authors (i.e., $27 \%$ for our sample as compared to their $20 \%$ ).

\subsubsection{Composite Equity-Based Incentives Measure}

Bergstresser and Philippon (2006) provide a composite measure of the CEOs' equity-based wealth incentives, calculated as the dollar change in the value of a CEO's stock and options holdings that correspond to a one percent increase in the company's stock price, normalized by the CEO's total compensation. Specifically,

$$
O N E P C T_{i, t}=0.01 * P R I C E_{i, t} *\left(S_{H A R E} S_{i, t}+O P T I O N S_{i, t}\right)
$$

and

$$
\text { IncentiveRatio }_{i, t}=O N E P C T_{i, t} /\left(O N E P C T_{i, t}+S A L A R Y_{i, t}+B O N U S_{i, t}\right) .
$$

where SHARES is the number of shares owned by the CEO and OPTIONS is the number of options held by the CEO. The IncentiveRatio variable thus captures the share of the CEO's total compensation coming from a one percentage point increase in the value of the equity of her company. Descriptive statistics for the estimated IncentiveRatio variable are provided in Table 2A and are broadly consistent with those reported by Bergstresser and Philippon (2006).

\subsection{Descriptive Evidence}

Pairwise correlations between accruals and real activities earnings management variables, together with CEO age and the young indicator variable, executive ownership and other explicit earnings management wealth- and compensation-based incentive variables, as well as other factors known to influence earnings management that are to be included as control variables in our multivariate regressions, are presented in Table 3. As shown, although CEO age and the 
young indicator variable are most often statistically significantly correlated with the explicit earnings management incentive variables defined above, the pairwise correlations between age and these contract-oriented incentives are not of economically interesting magnitudes.

In untabulated results we find that pairwise tests for differences between young and established CEOs are significant across all three measures of accounting discretion. Specifically, younger CEOs are associated with lower levels of discretionary accruals, lower levels of abnormal production costs, and higher levels of abnormal discretionary expenses relative to more established executives. This provides some preliminary support, on a univariate basis, in favor of our first two hypotheses.

\section{Hypotheses Testing}

\subsection{Model Specification}

Our formal hypothesis tests are based upon multivariate regressions of the three alternative measures of earnings management on our two alternative proxies for career stage as well as explicit contracting-based and other earnings management incentives. Our tests attempt to control for all of the variables that may be different across firms managed by younger versus more established executives. The control variables that we consider are those suggested by Cheng and Warfield (2005), and Cohen, et al (2008). Cheng and Warfield investigate the link between equity incentives and accruals-channeled earnings management. Cohen, et al (2008) examine how each of accruals and real activity earnings management varies from the preto post-Sarbanes-Oxley ("SOX") period. They treat the Cheng and Warfield (2005) equity interest variables as control variables in their regressions, as we do in our tests. Given the results of Cohen, et al (2008), we also include an indicator variable for the post-SOX period as a control variable in our regressions.

We estimate the following regression of earnings management activities on the control variables suggested by the prior literature, controls for the CEO's explicit earnings-based pay 
and equity incentives, and each of our two alternative age-based proxies for career stage:

$$
\begin{aligned}
\text { EM_Proxy }_{i, t}= & \gamma_{0}+\beta \text { CareerStage }_{i, t}+\gamma_{1} \text { CompensationIncentive }_{i, t} \\
& +\gamma_{2} \text { EquityIncentive }_{i, t}+\gamma_{3} \text { Size }_{i, t}+\gamma_{4} \text { Leverage }_{i, t}+\gamma_{5} \text { Risk }_{i, t}+\gamma_{6} \text { Growth }_{i, t} \\
& +\gamma_{7} \text { NOA }_{i, t-1}+\gamma_{8} \text { Litigation }_{i, t}+\gamma_{9} \text { ImplicitClaim }_{i, t}+\gamma_{10} \text { Big }_{-} \text {Auditor }_{i, t} \\
& +\gamma_{11} \Delta G D P+\gamma_{12} \text { Time }+\gamma_{13} \text { SOX }+\epsilon_{i, t}
\end{aligned}
$$

where EM_Proxy $y_{i, t}$ represents the dependent variable, $D A_{i, t}$, Abnormal_Prod_Costs $_{i, t}$, and Abnormal_Disc_Exps $s_{i, t}$ each in turn. CareerStage $e_{i, t}$ is defined alternatively as either the executive's age or with a young indicator variable set equal to one if the executive's age is less than the median age of CEOs in our sample, and zero otherwise. CompensationIncentive $e_{i, t}$ is defined alternatively as either the percentage of the CEO's total pay that is comprised of cash bonus compensation (Bonus\%) or the Bushman et al (2006) compensation-earnings coefficient (pay-earnings sensitivity) previously described. Our empirical measures for the equity incentive construct include the stand alone composite measure due to Bergstresser and Philippon (2006), IncentiveRatio ${ }_{i, t}$, or alternatively the contemporaneous inclusion of three separate measures capturing the percentage of the firm's common equity represented by the CEO's stock holdings (Owner\%), exercisable options (Ex_Option\%), and unexercisable options (Un_Option\%), respectively. The proxies for Size, Risk and Growth are market capitalization, beta, and book-to-market, respectively, and $S O X$ is an indicator variable for the Sarbanes-Oxley era that is set equal to one for fiscal periods ending after $2002 .{ }^{27}$ The remaining control variables are those suggested by the prior literature, detailed definitions of which are provided in the Appendix. ${ }^{28}$

\footnotetext{
${ }^{27}$ Although SOX and Time are highly correlated, the variance inflation factors for the regressions reported in our tables never exceed 3.61, well below the thresholds (varying from 5 to 10) that are commonly considered to be indicative of a significant collinearity problem. Because SOX and Time are designed to capture different constructs, we follow Cohen et al and run all of our regressions with both variables included in the models.

${ }^{28}$ In untabulated results, we also separately include return-on-assets (ROA) and the number of restricted shares held by the CEO as a percentage of the firm's total shares outstanding. ROA is significant in some models, but the restricted stock variable is never significant. In all cases our inferences regarding the influence of CEO career stage on the earnings management variables of interest are unaffected.
} 


\subsection{Empirical Results}

\subsubsection{Career Concerns and Earnings Management Via Accruals}

In Table 4 we present the results from regressions of equation (26) using discretionary accruals as the dependent variable. We present regressions using each of our two alternative age-based proxies for career stage, the test variable of interest, as well as each of two alternative controls for compensation- and equity-based incentives, respectively. Thus we display eight regression permutations. We use very conservative firm-CEO clustered standard errors to compute the t-statistics reported for all regression results reported in the tables.

As shown in Table 4, both of the age variables are significant in each of the eight abnormal accruals regression specifications. The positive coefficient on age, the continuous measure, indicates that older CEOs are associated with higher levels of discretionary accruals, consistent with Hypothesis 1. The negative coefficient of slightly less than $1 \%$ on the age indicator variable indicates that younger CEOs undertake, on average, about $1 \%$ of total assets less in accruals earnings management than their more established counterparts. Given that the mean and median range of ROA is about $6 \%$ for the entire sample, the difference in discretionary accruals across the early and later career stage CEOs is economically meaningful.

In the first four regressions, the percentage of compensation earned in the form of cash bonuses is positively and (at least weakly) significantly associated with accruals management, consistent with a long prior literature dating back to Healy (1985). With Bonus\% in the regression, none of the stock or option ownership variables are significant. When we control for earnings-based compensation incentives using the pay-earnings sensitivity coefficient, only the unexpired options ownership variable is (weakly) significant. Notably, the magnitudes and significance of the coefficents on the age variables of interest are stable across all of the regression specifications. Overall, our findings suggest that career stage is a statistically and economically significant determinant of CEOs' propensities to manage accruals, even after controlling for more direct CEO compensation and equity incentives as well as other known determinants of earnings management. Our results are thus consistent with the hypothesis generated from the career concerns based earnings management model, that more established 
executives tend to engage in higher levels of discretionary accruals.

\subsubsection{Career Concerns and Real Activities Management}

Table 5 presents the results of regressions of our real activities earnings management variables on the same career stage, compensation- and equity-based incentives, and other control variables considered in the previous section. In Panel $\mathrm{A}$ the dependent variable is abnormal production costs. Abnormal production costs arise because firms have overproduced relative to the current period's sales levels, with the result that some of the production costs incurred this period will be inventoried. Thus, higher abnormal production costs are presumed to result from a real activity that has been managed to increase the current period's income. Hence, under Hypothesis 2 we predict a positive association between CEO maturity and abnormal production costs. The results in Table $5 \mathrm{~A}$ are consistent with this; real earnings management activities in the form of increased abnormal production costs are an increasing function of executive maturity, as evidenced by the positive coefficient on the age variable across all specifications. We find similarly strong support for Hypothesis 2 when we use the alternative indicator variable for young executives as our proxy for career stage, as evidenced by the significant negative coefficient in each of the specifications that includes the young indicator variable. The coefficients ranging from -0.0157 to -0.0184 suggest that younger CEOs take approximately $1.6 \%$ to $1.8 \%$ of total assets less in abnormal production costs, which are economically significant magnitudes. Once again the magnitudes of the coefficients on the age variables of interest are stable across the various alternative combinations of controls for performance pay and ownership incentives, although the significance levels naturally decline somewhat as our sample size is reduced for the estimations of Models 5 through 8 .

Unlike in the abnormal accruals regressions, we find that Bonus\% is insignificant when it is included with the decomposed proxy for equity-based incentives, while each of the ownership variables is significant with the predicted sign. Bonus\% regains significance when equitybased incentives are measured using the composite IncentiveRatio variable, and the composite variable itself is also significant. The negative coefficients on the ownership and Incentive atio 
variables are consistent with the notion that, conditional upon age and bonus pay being in the model, higher levels of equity-based incentives lead executives to take more of a long-term view with respect to the management of the firm's real activities. When compensation-based earnings management incentives are captured using the pay-earnings sensitivity measure as in Models 5 through 8 in Table 5A, this incentive pay variable is significant and its coefficient takes the expected sign across all specifications; higher pay-earnings sensitivity induces executives to take more income-increasing abnormal production costs. All of the equity-based incentive measures are also significant with the expected signs across each of the last four specifications. The positive coefficient on SOX is also consistent with Cohen et al (2008) as well as Bartov and Cohen (2009), who find that real earnings management activities increase in the post-SOX period.

Panel B of Table 5 reports the results from regressions that use abnormal discretionary expenses as the dependent variable. Discretionary spending on R\&D or marketing, e.g., is expected to be reduced by more mature CEOs in order to increase short-term income and thereby positively impact their post-retirement labor market value. Alternatively stated, younger executives are expected to incur higher levels of discretionary expenses as they continue to invest in the firm's intellectual capital (e.g., patents, process improvements, name brands, etc.) at the optimal level so as to avoid any negative impact on their future wage due to the value destroying effects of such real earnings management. Hence, under Hypothesis 2 we predict a negative relationship between CEO maturity and discretionary expenses. The findings reported in Table 5B are consistent with this across all eight alternative specifications; the coefficient on age is negative and significant whereas that on the young indicator variable is consistently positive and significant. The coefficients on the young indicator variable range from 0.0196 to 0.0236 , suggesting that younger CEOs incur abnormal discretionary expenses of about $2 \%$ of assets more than older CEOs, which is once again an economically significant magnitude.

In the abnormal discretionary expenses regressions, Bonus\% is only marginally significant when the decomposed equity-based incentives are included, but not in the presence of the IncentiveRatio. In accordance with expectations, the pay-earnings sensitivity variable is neg- 
ative in each of the discretionary expense regression specifications, although not significantly so in any case. Similarly, the composite IncentiveRatio variable is statistically significant and carries the expected sign across all specifications, consistent with executives responding to this comprehensive measure of equity-based incentives when making real discretionary expense decisions. By contrast, the Owner\% and unexercisable options variables are never significant, while the exercisable options variable is significant with the expected sign in all four cases.

The evidence from Tables 5A and 5B provides strong support for Hypothesis 2 that younger CEOs engage in less income-increasing real activities earnings management, and the results hold across both of the dimensions of real activities examined. Our findings are economically and statistically significant, and they're robust to using two different age-based proxies for career stage, to controlling for two alternative state-of-the-art measures each for explicit compensation-based incentives and equity-based incentives for earnings manipulation, as well as to controlling for other candidate determinants of earnings management across firms.

\subsubsection{Earnings Management Trade-Offs of Younger Executives}

The results presented in Tables 4 and 5, when taken together, provide some preliminary evidence in support of the notion that younger CEOs prefer to engage in accruals management rather than to undertake real activities in order to increase earnings. In Table 4 we document that younger CEOs' abnormal accruals are slightly less than $1 \%$ of total assets lower than those of older CEOs, whereas the results in Table 5 suggest that their income-increasing discretionary real activities are lower by $1.6 \%$ to $2.4 \%$ of total assets. Thus, younger CEOs seem to face relatively greater disincentives to engage in real activities versus accruals-based earnings management relative to their older peers.

To address Hypothesis 3 even more directly, we investigate younger CEOs' relative propensities for income-increasing accruals versus real activities using a setting where the pressures to undertake some form of earnings management would seem to be intense. Specifically, in

order to identify a subset of firms where these pressures are likely to be binding, we follow Roychowdhury (2006) and develop a "suspects" sample of earnings management candidate 
firms which includes firm-year observations having analyst forecast errors in the range of zero to one-cent per share. ${ }^{29}$ We use the median of all analysts' final forecasts that were outstanding prior to the earnings announcement date to define our analyst consensus forecast measure. In untabulated specification checks, we find that using the mean final analyst forecast as the consensus leads to consistent results for all of our career stage test variables of interest.

Table 6 reports the results from regressions using 2,716 firm-year observations that qualify as "suspects" for analyst earnings target induced earnings management as defined above. The results shown in the first two columns indicate that there is no significant difference in accruals earnings management activities for younger versus older managers in cases where pressures for meeting or beating analyst expectations are presumed to be intense. This finding contrasts with the results presented above for the unconstrained general sample of firms, wherein we find that younger managers undertake less discretionary accruals than older executives, on average. For the case of real earnings management, however, the significant coefficients on the age variables in the regressions reported in the last four columns of Table 6 indicate that older managers undertake more real activities management than younger managers in circumstances of suspected heightened earnings performance pressures. Although the results for the continuous age variables may seem borderline significant, we remind the reader that the t-statistics are calculated using clustered standard errors and that our tests involve a directional hypothesis. Finally, in untabulated results we find that specifications using the Bergstresser and Philippon (2006) composite measure of equity incentives yield results for our age variables that are entirely consistent with those reported in Table 6 .

Overall, the evidence presented is supportive of Hypothesis 3 that under circumstances in which younger executives are presumed to face intense pressures to manage earnings to meet

\footnotetext{
${ }^{29}$ We acknowledge the possibility that, similar to many prior researchers who have used the identical "suspects" identification rule, we may have a somewhat noisy set of "suspect" firms. This ultimately works against our finding differential behavior for this group relative to the unconstrained sample underlying our primary tests. As further support for our research design choice, however, we note that Keung, Lin and Shih (2009) provide evidence that is consistent with the notion that earnings that are just above analyst estimates are more likely to have been managed. They show that the earnings response coefficients ("ERCs") for earnings surprises that are in the range of zero to one cent are significantly lower than for earnings surprises in adjacent ranges, suggesting that the market considers these earnings to be of lower quality. The authors also conclude that investors are right to be skeptical about earnings in the zero to one-cent range based upon the relation between these earnings and future earnings, and they further show that analysts react negatively to earnings surprises within this range.
} 
analyst forecasts, they tend to chose the "lesser of two evils" by managing accruals rather than undertaking real activities that may involve longer-term value destruction.

\subsection{Alternative Explanations and Robustness Checks}

\subsubsection{Time-Invariant Firm and CEO Characteristics}

One alternative explanation for our results is that firms that have greater income increasing earnings management tendencies also happen to select older CEOs. This could happen, for example, if firms that evince higher earnings management propensities choose older CEOs either because they expect there to be an alignment between CEO age and his willingness or ability to engage in earnings management, or simply because these firms tend to prefer the (real or perceived) sense of stability that comes with older managers. Alternatively, high earnings management propensity firms may not select CEOs on the basis of age, but on the basis of some other characteristic that is correlated with age. The result in any of these cases is that firms with greater earnings management propensities choose older CEOs, but CEO age has no causal effect on earnings management activity. This explanation suggests that better controls for firms' earnings management propensities should make the effect of CEO age disappear. We remind the reader that our earnings management dependent variables are all estimated at the industry level, that our earnings management regressions control for all of the previously documented determinants of earnings management, and furthermore that our significant results for the age variables are robust to using performance-matched discretionary accruals. Accordingly, we consider the evidence already presented to be strongly weighted against any form of selection story.

Nevertheless, in Panel A of Table 7 we report a robustness check in which each of our previous earnings management models is estimated with the inclusion of firm fixed effects in order to control for all observed and unobserved time-invariant firm characteristics that may be correlated with CEO age and income-increasing earnings management propensities. Each of the regressions includes all of the previously considered control variables reported in Tables 4 and 5, however for the sake of parsimony we do not table the control variable 
coefficients. As shown, our age variable remains significant across all regression specifications, and in all cases the significance levels are higher than in the previously reported regressions. The reason for the latter result is that the results presented in Tables 4 and 5 use extremely conservative firm-CEO clustered standard errors. The results in Panel A of Table 7 suggest that the documented relation between CEO age and earnings management behaviour is not due to firms with greater income-increasing earnings management propensities selecting older CEOs, assuming that earnings management propensity is a time-invariant firm characteristic.

An argument similar to the one raised above might suggest that the age results in our previous analyses are being driven by some time-invariant CEO characteristics which in turn are correlated with age in the cross-section. For example, CEOs that are more savvy or creative in business may exhibit lower earnings management propensities because "real" performance success is attainable without earnings management, and these characteristics are also in turn correlated with age because savvy and creative executives attain CEO status earlier. If earnings management behavior is really driven by such characteristics that are fixed over the CEO's lifetime, then including CEO fixed effects should lead the age variables to have insignificant coefficients. We therefore rerun our previous earnings management regressions with the inclusion of CEO fixed effects. In untabled results, we find that the coefficients on all of our age variables behave similar to those reported in Panel $\mathrm{A}$ of Table 7; the age variables remain significant, and the significance levels are higher on all of the coefficients. ${ }^{30}$

\subsubsection{Horizon Problems}

Prior research presents mixed evidence regarding the relation between earnings discretion and CEO retirement. For example, Dechow and Sloan (1991) present evidence in support of the notion that CEOs spend less on R\&D during their final years in office due to the horizon problem,

\footnotetext{
${ }^{30}$ Yet another alternative approach to addressing concerns regarding CEO and firm selection is to use propensity score matching. This method helps to overcome the possibility that the linear controls in the earnings management regressions are inadequate, and that age is picking up the nonlinear effects of firm characteristics on earnings management choices. We use propensity score matching to reweight observations in the young versus old CEO samples and to thereby create "ideal" comparison groups that have comparable covariate distributions and that differ only on age. Our preliminary results from these analyses indicate that younger CEOs still do less income-increasing earnings management, supporting the notion that our age results are not driven by distributional differences in observed covariates between firms with old versus young CEOs.
} 
while Murphy and Zimmerman (1993) find little support for the impact of horizon on R\&D expenditures using a different specification. For his sample of firms, Kalyta (2009) documents that income-increasing earnings management is present in the pre-retirement period only when the CEO's pension is based on firm performance. In contrast to the mixed empirical results in relation to the horizon problem, our findings that income-increasing behaviour is increasing in CEO age are robust across many specifications and alternative controls. Nevertheless, it's conceivable that our results could be explained by the horizon problem rather than the implicit career concerns that we contend if, for example, the older CEOs in our sample who are nearing retirement are primarily driving our empirical results. As a specification check, we therefore drop from our sample all CEOs whose age is equal to, or above, 63, being those CEOs who are close to normal retirement age. The results from this specification check are presented in Panel B of Table 7. As shown, our age variable remains significant across all specifications even for this reduced sample of observations.

We conclude from the combination of the mixed evidence in the prior horizon problem literature, together with the robustness of our own age results across all specifications, including one in which the CEOs who are most likely to be subject to a horizon problem are dropped from the sample, that implicit career concerns rather than horizon problems are the likely explanation for the age-based findings that we document.

\subsubsection{First-Year CEOs}

Pourciau (1993) presents evidence consistent with the hypothesis that incoming executives manage accruals in a way that decreases earnings in the year of the executive change and increases earnings in the following year. If first-year CEOs are systematically younger than continuing CEOs, as is likely to be the case, then these first-year CEO earnings management activities could be driving our cross-sectional results. In other words, it is not the CEO's age, but the fact that he is in his first year on the job with a new firm, that is causing discretionary earnings to be lower. We consider this alternative explanation to be unlikely because a "young" new CEO is likely to remain "young" in his second year on the job when the accruals have 
income-increasing effects. Thus, in our cross-sectional analyses any such first and second year effects are likely to offset one another. Notwithstanding this argument, we verify that first-year CEO observations are not driving our results by dropping all observations from our dataset involving a CEO's first year with a new firm, and then rerunning the previous regressions on the reduced sample. Although the significance of our coefficient estimates declines somewhat with the loss of observations, the magnitudes of the coefficients on our age variables are robust and remain significant across all regressions. We therefore conclude once again that career concerns, rather than rookie year CEO behavior in this case, is primarily driving the significance of our age variables in the cross-section.

\subsubsection{Other Explanations}

Yet another alternative explanation for our findings is that, rather than being motivated by career concerns as our model would suggest, younger CEOs are simply less savvy; they engage in less earnings management because they are less aware of the opportunities and benefits of doing so. Although we cannot empirically distinguish between this alternative and the career concerns explanation that we propose for our results, we consider the alternative to be

unlikely. The descriptive statistics for the executives in our sample suggest that the CEOs have a substantial number of years of experience, presumably in increasingly important managerial positions before arriving to the top post. Thus, it seems to us unlikely that these talented and successful executives who become CEOs of the largest 1500 publicly-traded US firms are unaware of the earnings management "games" (see Levitt (1998)), and thus the potential "benefits" to be derived therefrom, that have been the focus of considerable discussion and debate in academic research, MBA classrooms, and the financial press throughout the period of our study.

\section{$5 \quad$ Summary and Conclusion}

The recent survey evidence of Graham et al (2005) suggests that executives' career prospects are the most important determinant of corporate earnings management decisions, yet the 
extant academic literature has focused primarily on explicit contracting based explanations for this phenomenon. The point of our paper is to investigate, using theoretical and archival empirical methodologies, this apparent disconnect between executives' self-reported incentives for their earnings management choices versus those that have been the focus of the prior academic literature.

We first develop a theoretical model of earnings management, rooted in the classic career concerns framework of Holmstrom $(1982,1999)$, to motivate our empirical investigations. Our model alternatively incorporates the reversing nature of the accruals that are embedded in an earnings-based performance measurement system and the longer-term value destruction that is associated with real activities earnings management. The model generates the prediction that younger managers will have greater disincentives to undertake income-increasing accruals and real activities choices than their older counterparts.

Our primary empirical results provide support for this hypothesis. In extended tests we investigate the earnings management behavior of younger CEOs who are in circumstances that are consistent with intense pressures to meet an earnings benchmark, and we find that they seem to choose the "lesser of two evils" by managing accruals rather than undertaking real activities that could potentially have longer-term value-destroying effects. We subject our primary tests to a battery of robustness checks in order to discriminate between our careerbased hypotheses and alternative explanations for the significance of CEO age as a determinant of earnings management choices. Our career-based conclusions are robust to alternatively including firm or CEO fixed-effects, to alternatively dropping older CEOs or first-year CEOs from our sample, and to numerous alternative controls for the explicit CEO compensationand wealth-based incentives that have been the focus of prior studies.

Overall, we present robust and consistent new evidence that CEO age is a statistically and economically significant determinant of real activities and accruals-based earnings management levels. After numerous robustness checks, we conclude that non-contractual, implicit career stage incentives are important determinants of corporate earnings management behavior. Our findings are consistent with executives' own self-insights regarding their earnings management 
choices, but also suggest that CEO age may be a significant correlated omitted variable in prior academic earnings management studies. 


\section{Appendix A \\ Variable Definitions}

\section{A.1 Firm Characteristics:}

Total Assets: Compustat data6

Market cap: Market capitalization, calculated as the price per share (Compustat data199) multiplied by the number of shares outstanding (Compustat data25)

Sales: Compustat data12

Leverage: Long-term debt (Compustat data9) divided by total assets (Compustat data6)

Book-to-Market: Book value of equity (Compustat data60) divided by market capitalization

\section{A.2 Dependent Variables:}

DA: Discretionary accruals calculated using the modified Jones model described in Section 3.3 Abnormal prod costs: Abnormal production costs as defined in Section 3.4

Abnormal disc expenses: Abnormal discretionary expenses as defined in Section 3.4

\section{A.3 Independent Test Variables:}

Age The CEO's age during the year

Young indicator: 1 if the CEO's age is less than the median, 0 otherwise

\section{A.4 Compensation- and Wealth-based Incentive Variables:}

Bonus\%: Bonus compensation divided by total compensation

Pay-earnings sensitivity: A firm-specific estimate of the compensation-earnings coefficient ("CEC") as defined in Equation 23 in Section 3.5.1

Ex_options\%: Unexercised exercisable options divided by total outstanding shares Un_options\%: Unexercised un-exercisable options divided by total outstanding shares Owner\%: The sum of restricted stock grants this period plus the total number of shares held by the CEO at year end (excluding stock options) divided by total outstanding shares 
Number of options held: Total number of unexercised options

Value of options held: Dollar value of unexercised options as reported by the company

Incentive ratio: defined by Equation (25) in Section 3.5.2

\section{A.5 Other Control Variables:}

Implicit claim: A proxy for labor intensity, equals 1 minus the ratio of gross PP\&E (Compustat data7) to total assets (Compustat data6)

NOA(t-1): Prior year net operating assets $=$ Shareholders' equity (Compustat data216) minus cash and marketable securities (Compustat data1) plus total liabilities (Compustat data181) at the end of fiscal year t-1, all scaled by sales of fiscal year t-1 (Compustat data12)

Litigation: An indicator set equal to 1 if the firm belongs to a high litigation risk industry (pharmaceutical/biotechnology, SIC codes 2833-2836, 8731-8734; computers, SIC codes 35703577, 7370-7374; electronics, SIC codes 3600-3674; or retail, SIC cdoes 5200-5961), and zero otherwise

Big 5 auditor: An indicator set equal to one if the firm is audited by a big-5 audit firm, and zero otherwise

Delta_GDP: The \% change in the real GDP from the previous year

Beta: Value-weighted, firm-specific beta calculated from the contemporaneous year's daily returns

Time: The difference between the observation year and 1987

SOX_dummy: An indicator set equal to one for post-2002 observation years, and 0 otherwise 


\section{References}

[1] Ayers, B.C., Lefanowicz, C. and Robinson, J., 2002, "Do firms purchase the pooling method?" Review of Accounting Studies 7(1), 5-32.

[2] Baber, W.R., 1985, "Budget-based compensation and discretionary spending," The Accounting Review 60(1), 1-9.

[3] Baber, W.R., Fairfield, P.M., and Haggard, J.A., 1991, "The effect of concern about reported income on discretionary spending decisions: The case of research and development," The Accounting Review 66(6), 818-829.

[4] Bartov, E., 1993, "The timing of asset sales and earnings manipulation," The Accounting Review 68(4), 840-855.

[5] Bartov, E., and Cohen, D., 2009, "The "Numbers Game" in the pre- and post-SarbanesOxley Eras," Journal of Accounting, Auditing, and Finance 24(4), 505-534.

[6] Bartov, E., Givoly, D., and Hayn, C., 2002, "The Rewards to Meeting or Beating Earnings Expectations," Journal of Accounting \& Economics, 32(2), 173-204.

[7] Bens, D.A., Nagar, V., and Wong, M.H.F., 2002, "Real investment implications of employee stock option exercises," Journal of Accounting Research, 40(2), 359-393.

[8] Bens, D.A., Nagar, V., and Wong, M.H.F., 2003, "Employee stock options, EPS dilution, and stock repurchase," Journal of Accounting and Economics, 36(1-3), 51-90.

[9] Bergstresser, D. and Philippon, T., 2006, "CEO incentives and earnings management," Journal of Financial Economics, 80, 511-529.

[10] Bhojraj, S., P. Hribar, M. Picconi, and J. McInnis, 2009, "Making sense of cents: An examination of firms that marginally miss or beat analyst forecasts," Journal of Finance, $64(5), 2361-2388$. 
[11] Black, E.L., Sellers, K.F., and Manly, T.S., 1998, "Earnings management using asset sales: An international study of countries allowing noncurrent asset revaluation," Journal of Business Finance and Accounting, 25(9/10), 1287-1319.

[12] Bowen, R.M., DuCharme, L., and Shores, D., 1995, "Stakeholders' implicit claims and accounting method choice," Journal of Accounting and Economics, 20, 255-295.

[13] Brickley, J., Coles, J., and Linck, J., 1999, "What happens to CEOs after they retire? Evidence on career concerns and CEO incentives," Journal of Financial Economics, 52, 341-377.

[14] Brown, L., and Caylor, M., 2005, "A temporal analysis of quarterly earnings thresholds: Propensities and valuation consequences," The Accounting Review, 80 (2), 423-440.

[15] Burgstahler, D., and Dichev, I., 1997, "Earnings management to avoid earnings decreases and losses," Journal of Accounting and Economics, 24, No.1, 99-126.

[16] Bushee, B., 1998, "The influence of institutional investors on myopic R\&D investment behavior," Accounting Review 73(3), 305-333.

[17] Bushman, R., Engel, E., and Smith, A., 2006, "An analysis of the relation between the stewardship and valuation roles of earnings," Journal of Accounting Research, 44(1), 5383.

[18] Cheng, Q., and Warfield, T.D., 2005 "Equity incentives and earnings management," Accounting Review, 80, 441-476.

[19] Chevalier, J., and Ellison, G., 1999 "Career concerns of mutual fund managers," Quarterly Journal of Economics, 114, No.2, 389-432.

[20] Cohen, D., Dey, A., and Lys, T., 2008, "Real and accrual-based earnings management in the pre- and post-Sarbanes-Oxley periods," Accounting Review, 83(3), 757-787.

[21] Dai, Z., S. Radhakrishnan, and W. Zhang, 2009, Implicit and Explicit Incentives, and Management Earnings Forecasts, " unpublished working paper, UT, Dallas. 
[22] Degeorge, F., Patel, J., and Zeckhauser, R., 1999, "Earnings management to exceed thresholds," Journal of Business, 72(1), 1-33.

[23] Dechow, P. and Sloan, R., 1991, "Executive incentives and the horizon problem: An empirical investigation," Journal of Accounting and Economics, 14, 51-89.

[24] Dechow, P., Sloan, R., Sweeney, A., 1995, "Detecting earnings management," The Accounting Review, 70, 193-225.

[25] DeFond, M. and Jiambalvo, J., 1994, "Debt covenant violation and manipulation of accruals: accounting choice in troubled companies," Journal of Accounting and Economics $17,145-176$.

[26] Dhaliwal, D.S., Frankel, M., and Trezevant, R., 1994, "The taxable and book income motivations for a LIFO layer liquidation," Journal of Accounting Research, 32(2), 278289 .

[27] Dikolli, S., Mayew, W., and Nanda, D., 2009, "Performance surprises and uncertain managerial ability," unpublished working paper.

[28] Durtschi, C., and Easton, P., 2005, "Earnings management? The shapes of the frequency distributions of earnings metrics are not evidence ipso facto," Journal of Accounting Research, 43(4), 557-592.

[29] Elsaid, E., Davidson, W. N., Benson, B. W., 2008, "CEO compensation structure following succession: Evidence of optimal incentives with career concerns," unpublished working paper.

[30] Fama, E., 1980, "Agency problems and the theory of the firm," Journal of Political Economy 88, 288-307.

[31] Fama, E. and French, K., 1997, "Industry costs of equity," Journal of Financial Economics, 43, 153-193. 
[32] Graham, J.R., Harvey, C.R., and Rajgopal, S., 2005, "The economic imlications of corporate financial reporting," Journal of Accounting and Economics 40, 3-73.

[33] Gibbons, R. Murphy, K., 1992, "Optimal incentive contracts in the presence of career concerns: theory and evidence," Journal of Political Economy 100, 468-505.

[34] Greene, W. H., 1997, Econometric Analysis (3rd ed), Upper Saddle River: Prentice-Hall.

[35] Gunny, K., 2005, "What are the consequences of real earnings management?" Working paper, University of Colorado.

[36] Hand, J., 1989, "Did firms undertake debt-equity swaps for an accounting paper profit or true financial gain?", Accounting Review 64(4), 587-623.

[37] Hand, J., Hughes, P.J., and Sefcik, S.E., 1990, "Insubstance defeasances: Security price reactions and motivations," Journal of Accounting and Economics 13(1), 47-89.

[38] Healy, P., 1985, "The effect of bonus schemes on accounting decisions," Journal of Accounting and Economics 7, No.1-3, 85-107.

[39] Herrmann, D., Inoue, T. and Thomas, W.B., 2003, "The sale of assets to manage earnings in Japan," Journal of Accounting Research 41(1), 89-108.

[40] Holmstrom, B., 1982, "Managerial incentive schemes: a dynamic perspective," in Essays in Economics and Management in Honour of Lars Wahlbeck, Swenska Handelshogkolan, Helsinki.

[41] Holmstrom, B., 1999, "Managerial incentive problems: a dynamic perspective," Review of Economic Studies 66, 169-182.

[42] Hong, H., Kubik, J. and Soloman, A., 2000, "Security analysts' career concerns and herding of earnings forecasts," Rand Journal of Economics 31, 121-144.

[43] Hribar, P., Jenkins, N.T., and Johnson, W.B., 2006, "Stock repurchases as an earnings management device," Journal of Accounting and Economics, 41(1-2), 3-27. 
[44] Jackson, S.B. and Wilcox, W.E., 2000, "Do managers grant sales price reductions to avoid losses and declines in earnings and sales?" Quarterly Journal of Business and Economics $39(4), 3-20$.

[45] Kalyta, P., 2009, "Accounting discretion, horison problem, and CEO retirement benefits," The Accounting Review 84(5), 1553-1573.

[46] Kasznik, R., and McNichols, M., 2002, "Does meeting earnings expectations matter? Evidence from analyst forecast revisions and share prices," Journal of Accounting Research 40(3), 727-759.

[47] Keung, E., Lin, Z-X., Shih, Michael, 2009, "Does the stock market see a zero or small positive earnings surprise as a red flag?" Journal of Accounting Research, forthcoming.

[48] Key, K.G., 1997, "Political cost incentives for earnings management in the cable television industry," Journal of Accounting and Economics 23, No.3, 309-338.

[49] Kothari, S., Leone, A., and Wasley, C., 2005, "Performance matched discretionary accruals measures," Journal of Accounting and Economics 39(1), 163-197.

[50] Levitt, Arthur, 1998, "The numbers game," Unpublished remarks Available at http://www.sec.gov/news/speech/speecharchive/1998/spch220.txt.

[51] Levitt, Arthur, 2003, "Reclaiming the profession's heritage," Unpublished remarks delivered at the American Partners Meeting of KPMG LLP in Orlando, Fl., November 20, 2003.

[52] Liang, Pierre Jinghong, 2004, "Equilibrium earnings management, incentive contracts, and accounting standards," Contemporary Accounting Research 21(4), 685-717.

[53] Marquardt, C., and Wiedman, C., 2005, "Earnings management through transaction structuring: Contingent convertible debt and diluted earnings per share," Journal of Accounting Research 43(2), 205-243. 
[54] Matta, E., and P. Beamish, 2008, "The Accentuated CEOCareer Horizon Problem: Evidence from International Acquisitions, " Strategic Management Journal 29, 683-700.

[55] Murphy, K.J., and Zimmerman, J., 1993, "Financial performance surrounding CEO turnover," Journal of Accounting and Economics 16, 273-315.

[56] Payne, J., and Thomas, W., 2003, "The implications of using stock-split adjusted I/B/E/S data in empirical research," The Accounting Review 78(4), 1049-1067.

[57] Pourciau, S., 1993, "Earnings management and nonroutine executive changes," Journal of Accounting 83 Economics 16(1-3), 317-336.

[58] Ronen, J. and V. Yaari, 2008, Earnings Management, Springer Series in Accounting Scholarship, Springer Sciences + Business Media, LLC.

[59] Roychowdhury, S., 2006, "Earnings management through real activities manipulation," Journal of Accounting and Economics, 42, 335-370.

[60] Skinner, D. and Sloan, R., 2002, "Earnings surprises, growth expectations, and stock returns or don't let an earnings torpedo sink your portfolio," Review of Accounting Studies, $7(2 / 3), 289-312$.

[61] Smith, C., and Watts, R., 1982, "Incentive and tax effects of executive compensation plans, " Australian Journal of Management, 7(2), 139-157.

[62] Stein, J., 1989, "Efficient capital markets, inefficient firms: A model of myopic corporate behavior," The Quarterly Journal of Economics 104 (4), 655-669.

[63] Teoh, S.H., Welch, I., Wong, T.J., 1998a, "Earnings management and the long-run market performance of initial public offerings," Journal of Finance, 53, No.6, 1935-1974.

[64] Teoh, S.H., Welch, I., Wong, T.J., 1998b, "Earnings management and the underperformance of seasoned equity offerings," Journal of Financial Economics, 50, No.1, 63-99.

[65] Xu, R.Z., Taylor, G.K., Dugan, M.T., 2007, "Review of real earnings management literature," Journal of Accounting Literature, 26, 195-228. 
[66] Yim, S., 2010, "The Acquisitiveness of Youth: CEO Age and Acquisition Behavior," HBS, unpublished working paper. 
Table 1: Sample Selection Process

\begin{tabular}{|l|r|r|}
\hline ExecuComp-Compustat Universe for 1992-2006 (CEOs only) & 28,559 & $100 \%$ \\
\hline Exclude Financial Firms (SIC codes between 6000 and 6999) & $(4,140)$ & $(14.5 \%)$ \\
\hline Exclude missing or negative sales or assets & $(161)$ & $(0.6 \%)$ \\
\hline Non-missing values for all variables used in hypotheses tests & $(6,011)$ & $(21.0 \%)$ \\
\hline & & \\
\hline Total observations used in hypotheses tests & 18,247 & $63.9 \%$ \\
\hline Unique firms & 2,148 & \\
\hline Unique CEOs & 4,196 & \\
\hline
\end{tabular}


Table2: Descriptive Statistics

CEO Sample, 1992-2006

\begin{tabular}{|c|c|c|c|c|c|}
\hline \multicolumn{6}{|c|}{ Panel 2A: Descriptive and Independent Variables $(\mathrm{N}=18,247)$} \\
\hline & 25th & Mean & Median & 75th & Std Dev \\
\hline Total Assets (million \$) & 411.2 & 5296.6 & 1137.5 & 3713.5 & 19221 \\
\hline Market Cap (million \$) & 448.4 & 5895.8 & 1198.1 & 3737.8 & 20477 \\
\hline $\begin{array}{l}\text { Sales } \\
\text { (million \$) }\end{array}$ & 423.9 & 4309.7 & 1120.6 & 3367.1 & 12790 \\
\hline ROA & 3.18 & 5.91 & 6.60 & 10.80 & 13 \\
\hline Leverage & 0.05 & 0.20 & 0.18 & 0.30 & 0.17 \\
\hline Book-to-Market & 0.27 & 0.52 & 0.43 & 0.64 & 0.49 \\
\hline Big 5 auditor & & 0.97 & & & \\
\hline Delta_GDP & 2.5 & 3.13 & 3.6 & 4.0 & 1.1 \\
\hline Beta & 0.56 & 0.97 & 0.86 & 1.27 & 0.59 \\
\hline Age & 50 & 55.5 & 56 & 60 & 7.8 \\
\hline Time & 9 & 12.2 & 12 & 15 & 3.7 \\
\hline Bonus\% & 0.04 & 0.22 & 0.20 & 0.35 & 0.19 \\
\hline Pay-earnings sensitivity* & -0.14 & 3.49 & 2.11 & 6.23 & 8.98 \\
\hline $\begin{array}{l}\text { Number of options } \\
\text { held(thousand ) }\end{array}$ & 149.60 & 939.57 & 411.30 & 944.90 & 2432 \\
\hline $\begin{array}{l}\text { Value of options held } \\
\text { (thousand \$) }\end{array}$ & 103.75 & 10895.82 & 1612.10 & 7405.80 & 53210 \\
\hline Ex_options\% & 0.0007 & 0.0073 & 0.0036 & 0.0093 & 0.0114 \\
\hline Un_options\% & 0.0005 & 0.0048 & 0.0025 & 0.0063 & 0.0078 \\
\hline Owner\% & 0.0007 & 0.0258 & 0.0030 & 0.0143 & 0.0631 \\
\hline Incentive ratio & 0.0877 & 0.2504 & 0.1739 & 0.3372 & 0.2274 \\
\hline Implicit Claim & 0.34 & 0.54 & 0.57 & 0.75 & 0.26 \\
\hline NOA(t-1) & 0.60 & 1.22 & 0.86 & 1.36 & 2.90 \\
\hline Litigation & & 0.31 & & & \\
\hline SOX dummy & & 0.32 & & & \\
\hline \multicolumn{6}{|c|}{ Panel 2B: Dependent Variables $(\mathrm{N}=18,247)$} \\
\hline & 25th & Mean & Median & 75th & Std Dev \\
\hline DA & -0.047 & 0.016 & 0.001 & 0.046 & 0.231 \\
\hline Abnormal prod costs & -0.168 & -0.071 & -0.051 & 0.043 & 0.237 \\
\hline Abnormal disc expenses & -0.074 & 0.069 & 0.007 & 0.152 & 0.338 \\
\hline
\end{tabular}

*The sample size underlying the pay-earnings sensitivity variable is constrained to $\mathrm{N}=16,316$. 
Table 3: Correlation Table (CEO sample, 1992-2006, N=18,247 except for pay-earnings sensitivity, where N=16,316)

The upper-right triangle shows Pearson, the lower-left triangle shows Spearman. ${ }^{* * *}$ indicates p-value $<0.0001,{ }^{* *}$ indicates p-value $<0.001$, * indicates p-value $<0.01$

\begin{tabular}{|c|c|c|c|c|c|c|c|c|c|c|c|c|c|c|c|c|c|c|c|c|c|c|}
\hline & DA & A_prod & A_dis & Age & $\begin{array}{l}\begin{array}{l}\text { Young } \\
\text { ind }\end{array} \\
\text { _. }\end{array}$ & $\begin{array}{l}\text { Bonus } \\
\%\end{array}$ & $\begin{array}{l}\text { Pay- } \\
\text { earnings } \\
\text { sensitivity }\end{array}$ & $\begin{array}{l}\text { Owner } \\
\%\end{array}$ & Ex\% & Un\% & $\begin{array}{l}\begin{array}{l}\text { Incentive } \\
\text { ratio }\end{array} \\
\text { e }\end{array}$ & $\begin{array}{l}\text { Log } \\
\text { mkt } \\
\text { cap } \\
\end{array}$ & lev & Beta & B2M & NOA & $\begin{array}{l}\text { Litga } \\
\end{array}$ & $\begin{array}{l}\text { Implicit } \\
\text { Claim }\end{array}$ & Big5 & $\begin{array}{l}\text { Delta } \\
\text { GDP }\end{array}$ & Time & SOX \\
\hline $\mathrm{DA}$ & $\mathbb{T}$ & -0.01 & $\begin{array}{l}-0.06 \\
* * *\end{array}$ & $\begin{array}{l}0.02 \\
*\end{array}$ & $\begin{array}{l}-0.02 \\
*\end{array}$ & $\begin{array}{l}0.02 \\
*\end{array}$ & -0.01 & 0.01 & 0.00 & 0.00 & $\begin{array}{l}0.02 \\
*\end{array}$ & $\begin{array}{l}0.04 \\
* * *\end{array}$ & $\begin{array}{l}-0.03 \\
* * *\end{array}$ & 0.00 & $\begin{array}{l}0.03 \\
* * *\end{array}$ & $\begin{array}{l}-0.02 \\
*\end{array}$ & -0.00 & $\begin{array}{l}0.03 \\
* * *\end{array}$ & 0.01 & $\begin{array}{l}-0.07 \\
* * *\end{array}$ & $\begin{array}{l}0.05 \\
* * *\end{array}$ & $\begin{array}{l}0.03 \\
* * *\end{array}$ \\
\hline A_prod & $\begin{array}{l}0.04 \\
* * *\end{array}$ & I & $\begin{array}{l}-0.41 \\
* * *\end{array}$ & $\begin{array}{l}0.06 \\
* * *\end{array}$ & $\begin{array}{l}-0.05 \\
* * *\end{array}$ & -0.01 & $\begin{array}{l}0.03 \\
* *\end{array}$ & $\begin{array}{l}-0.03 \\
* * *\end{array}$ & $\begin{array}{l}-0.04 \\
* * * *\end{array}$ & $\begin{array}{l}-0.05 \\
* * *\end{array}$ & $\begin{array}{l}-0.15 \\
* * *\end{array}$ & $\begin{array}{l}-0.07 \\
* * *\end{array}$ & $\begin{array}{l}0.15 \\
* * * *\end{array}$ & $\begin{array}{l}-0.09 \\
* * * *\end{array}$ & $\begin{array}{l}0.03 \\
* * *\end{array}$ & $\begin{array}{l}0.05 \\
* * *\end{array}$ & $\begin{array}{l}-0.12 \\
* * *\end{array}$ & $\begin{array}{l}-0.10 \\
* * *\end{array}$ & -0.01 & -0.00 & 0.01 & $\begin{array}{l}0.03 \\
* *\end{array}$ \\
\hline A_dis & $\begin{array}{l}-0.10 \\
* * *\end{array}$ & $\begin{array}{l}-0.58 \\
* * *\end{array}$ & I & $\begin{array}{l}-0.08 \\
* * *\end{array}$ & $\begin{array}{l}0.07 \\
* * *\end{array}$ & $\begin{array}{l}-0.03 \\
* * *\end{array}$ & $\begin{array}{l}-0.03 \\
* *\end{array}$ & 0.02 & $\begin{array}{l}0.08 \\
* * *\end{array}$ & $\begin{array}{l}0.06 \\
* * *\end{array}$ & $\begin{array}{l}0.09 \\
* * *\end{array}$ & $\begin{array}{l}-0.03 \\
* * *\end{array}$ & $\begin{array}{l}-0.10 \\
* * *\end{array}$ & $\begin{array}{l}0.17 \\
* * *\end{array}$ & -0.01 & 0.01 & $\begin{array}{l}0.16 \\
* * *\end{array}$ & $\begin{array}{l}0.14 \\
* * *\end{array}$ & 0.01 & 0.01 & $\begin{array}{l}0.07 \\
* * *\end{array}$ & $\begin{array}{l}0.06 \\
* * *\end{array}$ \\
\hline Age & $\begin{array}{l}0.04 \\
* * *\end{array}$ & $\begin{array}{l}0.06 \\
* * *\end{array}$ & $\begin{array}{l}-0.11 \\
* * *\end{array}$ & $\mathbf{T}$ & $\begin{array}{l}-0.79 \\
* * *\end{array}$ & -0.01 & -0.00 & $\begin{array}{l}0.12 \\
* * *\end{array}$ & $\begin{array}{l}-0.02 \\
*\end{array}$ & $\begin{array}{l}-0.14 \\
* * *\end{array}$ & $\begin{array}{l}0.05 \\
* * *\end{array}$ & $\begin{array}{l}0.07 \\
* * *\end{array}$ & $\begin{array}{l}0.04 \\
* * *\end{array}$ & $\begin{array}{l}-0.13 \\
* * *\end{array}$ & 0.01 & -0.01 & $\begin{array}{l}-0.17 \\
* * *\end{array}$ & $\begin{array}{l}-0.11 \\
* * *\end{array}$ & 0.00 & $\begin{array}{l}0.03 \\
* * *\end{array}$ & $\begin{array}{l}-0.02 \\
* *\end{array}$ & -0.00 \\
\hline Young_ind & $\begin{array}{l}-0.04 \\
* * *\end{array}$ & $\begin{array}{l}-0.05 \\
* * *\end{array}$ & $\begin{array}{l}0.09 \\
* * *\end{array}$ & $\begin{array}{l}-0.87 \\
* * *\end{array}$ & I & 0.01 & -0.00 & $\begin{array}{l}-0.08 \\
* * *\end{array}$ & $\begin{array}{l}0.02 \\
*\end{array}$ & $\begin{array}{l}0.11 \\
* * *\end{array}$ & $\begin{array}{l}-0.04 \\
* * *\end{array}$ & $\begin{array}{l}-0.09 \\
* * *\end{array}$ & $\begin{array}{l}-0.03 \\
* * *\end{array}$ & $\begin{array}{l}0.10 \\
* * *\end{array}$ & -0.01 & 0.01 & $\begin{array}{l}0.15 \\
* * *\end{array}$ & $\begin{array}{l}0.09 \\
* * *\end{array}$ & 0.00 & $\begin{array}{l}-0.02 \\
*\end{array}$ & 0.02 & 0.00 \\
\hline Bonus\% & $\begin{array}{l}0.03 \\
* *\end{array}$ & $\begin{array}{l}-0.02 \\
*\end{array}$ & $\begin{array}{l}-0.04 \\
* * *\end{array}$ & -0.02 & 0.01 & 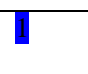 & $\begin{array}{l}0.03 \\
* * *\end{array}$ & -0.02 & -0.02 & 0.00 & $\begin{array}{l}-0.16 \\
* * *\end{array}$ & $\begin{array}{l}0.12 \\
* * *\end{array}$ & 0.01 & $\begin{array}{l}-0.07 \\
* * *\end{array}$ & $\begin{array}{l}-0.03 \\
* * * *\end{array}$ & -0.02 & $\begin{array}{l}-0.10 \\
* * *\end{array}$ & $\begin{array}{l}0.02 \\
*\end{array}$ & -0.01 & 0.02 & -0.01 & 0.01 \\
\hline $\begin{array}{l}\text { Pay- } \\
\text { earnings } \\
\text { sensitivity }\end{array}$ & 0.01 & $\begin{array}{l}0.08 \\
* * *\end{array}$ & $\begin{array}{l}-0.07 \\
* * *\end{array}$ & $\begin{array}{l}0.07 \\
* * *\end{array}$ & $\begin{array}{l}-0.07 \\
* * *\end{array}$ & $\begin{array}{l}0.09 \\
* * *\end{array}$ & I & 0.00 & $\begin{array}{l}-0.04 \\
* * *\end{array}$ & $\begin{array}{l}-0.02 \\
*\end{array}$ & $\begin{array}{l}-0.03 \\
* *\end{array}$ & $\begin{array}{l}0.02 \\
*\end{array}$ & $\begin{array}{l}0.04 \\
* * *\end{array}$ & -0.01 & 0.02 & -0.00 & $\begin{array}{l}-0.02 \\
*\end{array}$ & $\begin{array}{l}-0.03 \\
* *\end{array}$ & 0.00 & 0.01 & -0.01 & -0.01 \\
\hline Owner\% & -0.00 & -0.00 & 0.01 & $\begin{array}{l}0.13 \\
* * *\end{array}$ & $\begin{array}{l}-0.10 \\
* * *\end{array}$ & $\begin{array}{l}-0.07 \\
* * *\end{array}$ & $\begin{array}{l}-0.03 \\
*\end{array}$ & T & $\begin{array}{l}0.04 \\
* * *\end{array}$ & 0.00 & $\begin{array}{l}0.58 \\
* * *\end{array}$ & $\begin{array}{l}-0.16 \\
* * *\end{array}$ & $\begin{array}{l}-0.09 \\
* * *\end{array}$ & 0.00 & -0.00 & $\begin{array}{l}-0.03 \\
* * *\end{array}$ & $\begin{array}{l}0.03 \\
* *\end{array}$ & $\begin{array}{l}0.08 \\
* * *\end{array}$ & $\begin{array}{l}-0.07 \\
* * *\end{array}$ & 0.01 & $\begin{array}{l}-0.06 \\
* * *\end{array}$ & $\begin{array}{l}-0.06 \\
* * *\end{array}$ \\
\hline Ex\% & -0.00 & $\begin{array}{l}-0.02 \\
*\end{array}$ & $\begin{array}{l}0.08 \\
* * *\end{array}$ & $\begin{array}{l}-0.04 \\
* * *\end{array}$ & $\begin{array}{l}0.03 \\
* * *\end{array}$ & -0.00 & $\begin{array}{l}-0.06 \\
* * *\end{array}$ & $\begin{array}{l}0.19 \\
* * *\end{array}$ & I & $\begin{array}{l}0.26 \\
* * *\end{array}$ & $\begin{array}{l}0.10 \\
* * *\end{array}$ & $\begin{array}{l}-0.26 \\
* * *\end{array}$ & $\begin{array}{l}-0.02 \\
*\end{array}$ & $\begin{array}{l}0.06 \\
* * *\end{array}$ & 0.02 & $\begin{array}{l}0.06 \\
* * * *\end{array}$ & $\begin{array}{l}0.09 \\
* * *\end{array}$ & $\begin{array}{l}0.13 \\
* * *\end{array}$ & $\begin{array}{l}-0.04 \\
* * *\end{array}$ & $\begin{array}{l}-0.06 \\
* * *\end{array}$ & $\begin{array}{l}0.14 \\
* * *\end{array}$ & $\begin{array}{l}0.11 \\
* * *\end{array}$ \\
\hline Un\% & 0.01 & $\begin{array}{l}-0.05 \\
* * *\end{array}$ & $\begin{array}{l}0.09 \\
* * *\end{array}$ & $\begin{array}{l}-0.19 \\
* * *\end{array}$ & $\begin{array}{l}0.16 \\
* * *\end{array}$ & $\begin{array}{l}0.04 \\
* * *\end{array}$ & $\begin{array}{l}-0.05 \\
* * *\end{array}$ & $\begin{array}{l}0.09 \\
* * *\end{array}$ & $\begin{array}{l}0.44 \\
* * *\end{array}$ & I & $\begin{array}{l}0.07 \\
* * *\end{array}$ & $\begin{array}{l}-0.24 \\
* * *\end{array}$ & $\begin{array}{l}-0.03 \\
* *\end{array}$ & $\begin{array}{l}0.07 \\
* * *\end{array}$ & -0.00 & 0.01 & $\begin{array}{l}0.13 \\
* * *\end{array}$ & $\begin{array}{l}0.15 \\
* * *\end{array}$ & 0.01 & $\begin{array}{l}-0.04 \\
* * * *\end{array}$ & $\begin{array}{l}0.04 \\
* * *\end{array}$ & -0.02 \\
\hline $\begin{array}{l}\text { Incentive } \\
\text { ratio }\end{array}$ & 0.01 & $\begin{array}{l}-0.18 \\
* * *\end{array}$ & $\begin{array}{l}0.11 \\
* * *\end{array}$ & $\begin{array}{l}0.05 \\
* * * *\end{array}$ & $\begin{array}{l}-0.04 \\
* * *\end{array}$ & $\begin{array}{l}-0.17 \\
* * *\end{array}$ & $\begin{array}{l}-0.09 \\
* * *\end{array}$ & $\begin{array}{l}0.47 \\
* * *\end{array}$ & $\begin{array}{l}0.18 \\
* * *\end{array}$ & $\begin{array}{l}0.13 \\
* * *\end{array}$ & I & $\begin{array}{l}0.27 \\
* * * *\end{array}$ & $\begin{array}{l}-0.14 \\
* * *\end{array}$ & $\begin{array}{l}0.19 \\
* * *\end{array}$ & $\begin{array}{l}-0.03 \\
* * *\end{array}$ & 0.00 & $\begin{array}{l}0.17 \\
* * *\end{array}$ & $\begin{array}{l}0.19 \\
* * *\end{array}$ & 0.01 & $\begin{array}{l}-0.02 \\
* *\end{array}$ & $\begin{array}{l}0.04 \\
* * *\end{array}$ & -0.02 \\
\hline $\begin{array}{l}\text { Log mkt } \\
\text { cap }\end{array}$ & $\begin{array}{l}0.03 \\
* * *\end{array}$ & $\begin{array}{l}-0.09 \\
* * *\end{array}$ & $\begin{array}{l}-0.04 \\
* * *\end{array}$ & $\begin{array}{l}0.08 \\
* * *\end{array}$ & $\begin{array}{l}-0.08 \\
* * *\end{array}$ & $\begin{array}{l}0.14 \\
* * *\end{array}$ & $\begin{array}{l}0.04 \\
* * *\end{array}$ & $\begin{array}{l}-0.33 \\
* * *\end{array}$ & $\begin{array}{l}-0.27 \\
* * *\end{array}$ & $\begin{array}{l}-0.24 \\
* * *\end{array}$ & $\begin{array}{l}0.31 \\
* * *\end{array}$ & T & 0.01 & $\begin{array}{l}0.08 \\
* * *\end{array}$ & $\begin{array}{l}-0.02 \\
*\end{array}$ & $\begin{array}{l}0.03 \\
* *\end{array}$ & $\begin{array}{l}-0.02 \\
*\end{array}$ & $\begin{array}{l}-0.04 \\
* * *\end{array}$ & $\begin{array}{l}0.09 \\
* * *\end{array}$ & -0.01 & $\begin{array}{l}0.10 \\
* * * *\end{array}$ & $\begin{array}{l}0.09 \\
* * *\end{array}$ \\
\hline lev & -0.02 & $\begin{array}{l}0.19 \\
* * *\end{array}$ & $\begin{array}{l}-0.16 \\
* * *\end{array}$ & $\begin{array}{l}0.07 \\
* * *\end{array}$ & $\begin{array}{l}-0.06 \\
* * *\end{array}$ & $\begin{array}{l}0.02 \\
* *\end{array}$ & $\begin{array}{l}0.12 \\
* * *\end{array}$ & $\begin{array}{l}-0.10 \\
* * *\end{array}$ & $\begin{array}{l}-0.04 \\
* * * *\end{array}$ & $\begin{array}{l}-0.07 \\
* * * *\end{array}$ & $\begin{array}{l}-0.17 \\
* * *\end{array}$ & $\begin{array}{l}0.08 \\
* * *\end{array}$ & D & $\begin{array}{l}-0.18 \\
* * *\end{array}$ & -0.00 & $\begin{array}{l}0.09 \\
* * *\end{array}$ & $\begin{array}{l}-0.25 \\
* * *\end{array}$ & $\begin{array}{l}-0.27 \\
* * *\end{array}$ & $\begin{array}{l}0.04 \\
* * *\end{array}$ & 0.00 & -0.01 & -0.02 \\
\hline Beta & $\begin{array}{l}-0.04 \\
* * *\end{array}$ & $\begin{array}{l}-0.08 \\
* * *\end{array}$ & $\begin{array}{l}0.19 \\
* * *\end{array}$ & $\begin{array}{l}-0.12 \\
* * *\end{array}$ & $\begin{array}{l}0.09 \\
* * *\end{array}$ & $\begin{array}{l}-0.07 \\
* * *\end{array}$ & $\begin{array}{l}-0.09 \\
* * *\end{array}$ & $\begin{array}{l}0.03 \\
* * *\end{array}$ & $\begin{array}{l}0.10 \\
* * *\end{array}$ & $\begin{array}{l}0.10 \\
* * *\end{array}$ & $\begin{array}{l}0.20 \\
* * *\end{array}$ & $\begin{array}{l}0.11 \\
* * *\end{array}$ & $\begin{array}{l}-0.23 \\
* * *\end{array}$ & T & $\begin{array}{l}-0.04 \\
* * *\end{array}$ & 0.01 & $\begin{array}{l}0.34 \\
* * * *\end{array}$ & $\begin{array}{l}0.27 \\
* * *\end{array}$ & $\begin{array}{l}0.02 \\
* *\end{array}$ & $\begin{array}{l}-0.06 \\
* * *\end{array}$ & $\begin{array}{l}0.18 \\
* * *\end{array}$ & $\begin{array}{l}0.24 \\
* * *\end{array}$ \\
\hline B2M & -0.00 & $\begin{array}{l}0.27 \\
* * *\end{array}$ & $\begin{array}{l}-0.16 \\
* * *\end{array}$ & $\begin{array}{l}0.06 \\
* * *\end{array}$ & $\begin{array}{l}-0.04 \\
* * *\end{array}$ & $\begin{array}{l}-0.08 \\
* * *\end{array}$ & $\begin{array}{l}0.15 \\
* * *\end{array}$ & 0.00 & $\begin{array}{l}0.05 \\
* * *\end{array}$ & $\begin{array}{l}-0.04 \\
* * *\end{array}$ & $\begin{array}{l}-0.40 \\
* * *\end{array}$ & $\begin{array}{l}-0.40 \\
* * *\end{array}$ & $\begin{array}{l}0.15 \\
* * *\end{array}$ & $\begin{array}{l}-0.19 \\
* * *\end{array}$ & T & 0.00 & -0.00 & -0.01 & -0.01 & -0.01 & $\begin{array}{l}-0.02 \\
*\end{array}$ & $\begin{array}{l}-0.03 \\
* * *\end{array}$ \\
\hline $\mathrm{NOA}$ & -0.01 & $\begin{array}{l}0.03 \\
* *\end{array}$ & $\begin{array}{l}-0.05 \\
* * *\end{array}$ & $\begin{array}{l}0.04 \\
* * *\end{array}$ & $\begin{array}{l}-0.04 \\
* * *\end{array}$ & -0.02 & $\begin{array}{l}-0.03 \\
* *\end{array}$ & $\begin{array}{l}-0.23 \\
* * *\end{array}$ & $\begin{array}{l}-0.07 \\
* * *\end{array}$ & $\begin{array}{l}-0.14 \\
* * *\end{array}$ & $\begin{array}{l}-0.06 \\
* * *\end{array}$ & $\begin{array}{l}0.23 \\
* * * *\end{array}$ & $\begin{array}{l}0.40 \\
* * *\end{array}$ & $\begin{array}{l}-0.10 \\
* * *\end{array}$ & $\begin{array}{l}0.11 \\
* * *\end{array}$ & T & $\begin{array}{l}-0.03 \\
* * *\end{array}$ & $\begin{array}{l}-0.07 \\
* * *\end{array}$ & 0.01 & -0.02 & 0.00 & -0.00 \\
\hline Litgation & $\begin{array}{l}-0.03 \\
* * *\end{array}$ & $\begin{array}{l}-0.13 \\
* * *\end{array}$ & $\begin{array}{l}0.21 \\
* * *\end{array}$ & $\begin{array}{l}-0.17 \\
* * *\end{array}$ & $\begin{array}{l}0.15 \\
* * *\end{array}$ & $\begin{array}{l}-0.11 \\
* * *\end{array}$ & $\begin{array}{l}-0.11 \\
* * *\end{array}$ & $\begin{array}{l}0.04 \\
* * *\end{array}$ & $\begin{array}{l}0.10 \\
* * * *\end{array}$ & $\begin{array}{l}0.14 \\
* * *\end{array}$ & $\begin{array}{l}0.18 \\
* * *\end{array}$ & $\begin{array}{l}-0.03 \\
* * *\end{array}$ & $\begin{array}{l}-0.30 \\
* * *\end{array}$ & $\begin{array}{l}0.33 \\
* * *\end{array}$ & $\begin{array}{l}-0.15 \\
* * *\end{array}$ & $\begin{array}{l}-0.26 \\
* * *\end{array}$ & T & $\begin{array}{l}0.23 \\
* * *\end{array}$ & 0.01 & $\begin{array}{l}-0.03 \\
* *\end{array}$ & $\begin{array}{l}0.05 \\
* * *\end{array}$ & 0.01 \\
\hline $\begin{array}{l}\text { Implicit } \\
\text { Claim }\end{array}$ & -0.02 & $\begin{array}{l}-0.12 \\
* * *\end{array}$ & $\begin{array}{l}0.20 \\
* * *\end{array}$ & $\begin{array}{l}-0.13 \\
* * *\end{array}$ & $\begin{array}{l}0.11 \\
* * *\end{array}$ & 0.00 & $\begin{array}{l}-0.14 \\
* * *\end{array}$ & $\begin{array}{l}0.14 \\
* * * *\end{array}$ & $\begin{array}{l}0.18 \\
* * *\end{array}$ & $\begin{array}{l}0.20 \\
* * *\end{array}$ & $\begin{array}{l}0.21 \\
* * *\end{array}$ & $\begin{array}{l}-0.06 \\
* * *\end{array}$ & $\begin{array}{l}-0.32 \\
* * *\end{array}$ & $\begin{array}{l}0.28 \\
* * *\end{array}$ & $\begin{array}{l}-0.17 \\
* * *\end{array}$ & $\begin{array}{l}-0.25 \\
* * * *\end{array}$ & $\begin{array}{l}0.23 \\
* * *\end{array}$ & I & -0.01 & $\begin{array}{l}-0.06 \\
* * * *\end{array}$ & $\begin{array}{l}0.13 \\
* * *\end{array}$ & $\begin{array}{l}0.08 \\
* * *\end{array}$ \\
\hline Big5 & 0.01 & -0.01 & 0.02 & -0.00 & 0.00 & -0.00 & 0.02 & $\begin{array}{l}-0.03 \\
* *\end{array}$ & -0.01 & $\begin{array}{l}0.03 \\
* * *\end{array}$ & $\begin{array}{l}0.05 \\
* * *\end{array}$ & $\begin{array}{l}0.09 \\
* * *\end{array}$ & $\begin{array}{l}0.04 \\
* * *\end{array}$ & $\begin{array}{l}0.03 \\
* * *\end{array}$ & $\begin{array}{l}-0.05 \\
* * *\end{array}$ & 0.01 & 0.01 & -0.02 & T & -0.01 & 0.01 & -0.01 \\
\hline $\begin{array}{l}\text { Delta } \\
\text { GDP }\end{array}$ & $\begin{array}{l}-0.02 \\
*\end{array}$ & -0.01 & -0.02 & $\begin{array}{l}0.03 \\
* * *\end{array}$ & -0.02 & $\begin{array}{l}0.02 \\
*\end{array}$ & 0.01 & 0.01 & $\begin{array}{l}-0.09 \\
* * *\end{array}$ & $\begin{array}{l}-0.07 \\
* * *\end{array}$ & -0.02 & -0.02 & 0.02 & $\begin{array}{l}-0.08 \\
* * *\end{array}$ & $\begin{array}{l}-0.08 \\
* * *\end{array}$ & $\begin{array}{l}-0.03 \\
* * * *\end{array}$ & $\begin{array}{l}-0.03 \\
* *\end{array}$ & $\begin{array}{l}-0.07 \\
* * *\end{array}$ & -0.00 & t & $\begin{array}{l}-0.34 \\
* * *\end{array}$ & $\begin{array}{l}-0.10 \\
* * *\end{array}$ \\
\hline Time & $\begin{array}{l}-0.02 \\
*\end{array}$ & 0.02 & $\begin{array}{l}0.06 \\
* * *\end{array}$ & $\begin{array}{l}-0.03 \\
* *\end{array}$ & 0.02 & -0.01 & -0.02 & $\begin{array}{l}-0.02 \\
*\end{array}$ & $\begin{array}{l}0.22 \\
* * *\end{array}$ & $\begin{array}{l}0.09 \\
* * *\end{array}$ & $\begin{array}{l}0.08 \\
* * *\end{array}$ & $\begin{array}{l}0.10 \\
* * *\end{array}$ & $\begin{array}{l}-0.03 \\
* * *\end{array}$ & $\begin{array}{l}0.20 \\
* * *\end{array}$ & 0.01 & $\begin{array}{l}0.03 \\
* * *\end{array}$ & $\begin{array}{l}0.05 \\
* * *\end{array}$ & $\begin{array}{l}0.14 \\
* * *\end{array}$ & 0.01 & $\begin{array}{l}-0.43 \\
* * * *\end{array}$ & I & $\begin{array}{l}0.80 \\
* * *\end{array}$ \\
\hline SOX & $\begin{array}{l}-0.04 \\
* * *\end{array}$ & $\begin{array}{l}0.03 \\
* * *\end{array}$ & $\begin{array}{l}0.05 \\
* * *\end{array}$ & -0.01 & 0.00 & 0.00 & -0.01 & $\begin{array}{l}-0.03 \\
* * *\end{array}$ & $\begin{array}{l}0.16 \\
* * *\end{array}$ & 0.02 & 0.01 & $\begin{array}{l}0.09 \\
* * *\end{array}$ & $\begin{array}{l}-0.03 \\
* * *\end{array}$ & $\begin{array}{l}0.29 \\
* * *\end{array}$ & $\begin{array}{l}0.04 \\
* * *\end{array}$ & $\begin{array}{l}0.05 \\
* * *\end{array}$ & 0.01 & $\begin{array}{l}0.08 \\
* * *\end{array}$ & -0.01 & $\begin{array}{l}-0.26 \\
* * *\end{array}$ & $\begin{array}{l}0.81 \\
* * *\end{array}$ & 1 \\
\hline
\end{tabular}


Table 4: Multiple Regression Results On Discretionary Accruals

CEO Sample, 1992-2006

(We use firm-CEO clustered standard errors to compute the reported t-statistics)

\begin{tabular}{|c|c|c|c|c|c|c|c|c|}
\hline & \multicolumn{8}{|c|}{$\begin{array}{c}\text { Dependent Variable = } \\
\text { DA }\end{array}$} \\
\hline & \multicolumn{4}{|c|}{$\mathrm{N}=18247$} & \multicolumn{4}{|c|}{$\mathrm{N}=16316$} \\
\hline & Model1 & Model2 & Model3 & Model4 & Model5 & Model6 & Model7 & Model8 \\
\hline Intercept & $\begin{array}{l}-0.0365 \\
(-1.81)\end{array}$ & $\begin{array}{l}-0.0053 \\
(-0.35)\end{array}$ & $\begin{array}{l}-0.0295 \\
(-1.46)\end{array}$ & $\begin{array}{l}0.0015 \\
(0.10)\end{array}$ & $\begin{array}{l}-0.0267 \\
(-1.25)\end{array}$ & $\begin{array}{l}0.0045 \\
(0.28)\end{array}$ & $\begin{array}{l}-0.0210 \\
(-0.98)\end{array}$ & $\begin{array}{l}0.0098 \\
(0.62)\end{array}$ \\
\hline Age & $\begin{array}{l}0.0005 \\
(1.97)\end{array}$ & & $\begin{array}{l}0.0005 \\
(2.00) \\
\end{array}$ & & $\begin{array}{l}\text { 0.0005 } \\
(1.96)\end{array}$ & & $\begin{array}{l}\text { 0.0005 } \\
(1.95)\end{array}$ & \\
\hline Young indicator & & $\begin{array}{l}-0.0084 \\
(-2.36) \\
\end{array}$ & & $\begin{array}{l}-0.0085 \\
(-2.39) \\
\end{array}$ & & $\begin{array}{l}-0.0069 \\
(-1.87) \\
\end{array}$ & & $\begin{array}{l}-0.0069 \\
(-1.87) \\
\end{array}$ \\
\hline Bonus\% & $\begin{array}{l}0.0168 \\
(1.81)\end{array}$ & $\begin{array}{l}0.0169 \\
(1.83)\end{array}$ & $\begin{array}{l}0.0191 \\
(2.06)\end{array}$ & $\begin{array}{l}0.0193 \\
(2.08)\end{array}$ & & & & \\
\hline Pay-earnings sensitivity & & & & & $\begin{array}{l}-0.0000 \\
(-0.97)\end{array}$ & $\begin{array}{l}-0.0000 \\
(-0.99)\end{array}$ & $\begin{array}{l}-0.0000 \\
(-0.96)\end{array}$ & $\begin{array}{l}-0.0000 \\
(-0.98)\end{array}$ \\
\hline Owner\% & $\begin{array}{l}0.0355 \\
(1.07)\end{array}$ & $\begin{array}{l}0.0368 \\
(1.12)\end{array}$ & & & $\begin{array}{l}0.0362 \\
(1.05)\end{array}$ & $\begin{array}{l}0.0389 \\
(1.14)\end{array}$ & & \\
\hline Un_option\% & $\begin{array}{l}0.3002 \\
(1.27)\end{array}$ & $\begin{array}{l}0.2887 \\
(1.23)\end{array}$ & & & $\begin{array}{l}0.5276 \\
(1.89)\end{array}$ & $\begin{array}{l}0.5068 \\
(1.83)\end{array}$ & & \\
\hline Ex_option\% & $\begin{array}{l}0.0332 \\
(0.20)\end{array}$ & $\begin{array}{l}0.0339 \\
(0.20)\end{array}$ & & & $\begin{array}{l}-0.1431 \\
(-0.85)\end{array}$ & $\begin{array}{l}-0.1401 \\
(-0.83)\end{array}$ & & \\
\hline Incentive_ratio & & & $\begin{array}{l}0.0082 \\
(0.89)\end{array}$ & $\begin{array}{l}0.0086 \\
(0.94)\end{array}$ & & & $\begin{array}{l}0.0014 \\
(0.15)\end{array}$ & $\begin{array}{l}0.0021 \\
(0.22)\end{array}$ \\
\hline Log(MktCap) & $\begin{array}{l}0.0057 \\
(4.45)\end{array}$ & $\begin{array}{l}0.0057 \\
(4.39)\end{array}$ & $\begin{array}{l}0.0048 \\
(3.91)\end{array}$ & $\begin{array}{l}0.0047 \\
(3.83)\end{array}$ & $\begin{array}{l}0.0058 \\
(4.45)\end{array}$ & $\begin{array}{l}0.0058 \\
(4.43)\end{array}$ & $\begin{array}{l}0.0053 \\
(4.25)\end{array}$ & $\begin{array}{l}0.0052 \\
(4.19)\end{array}$ \\
\hline Leverage & $\begin{array}{l}-0.0304 \\
(-2.40) \\
\end{array}$ & $\begin{array}{l}-0.0303 \\
(-2.40) \\
\end{array}$ & $\begin{array}{l}-0.0301 \\
(-2.38) \\
\end{array}$ & $\begin{array}{l}-0.0300 \\
(-2.38) \\
\end{array}$ & $\begin{array}{l}-0.0269 \\
(-1.93) \\
\end{array}$ & $\begin{array}{l}-0.0268 \\
(-1.92) \\
\end{array}$ & $\begin{array}{l}-0.0275 \\
(-1.97) \\
\end{array}$ & $\begin{array}{l}-0.0274 \\
(-1.97) \\
\end{array}$ \\
\hline Beta & $\begin{array}{l}-0.0061 \\
(-1.49)\end{array}$ & $\begin{array}{l}-0.0061 \\
(-1.51)\end{array}$ & $\begin{array}{l}-0.0062 \\
(-1.52)\end{array}$ & $\begin{array}{l}-0.0063 \\
(-1.54)\end{array}$ & $\begin{array}{l}-0.0073 \\
(-1.67)\end{array}$ & $\begin{array}{l}-0.0075 \\
(-1.70)\end{array}$ & $\begin{array}{l}-0.0072 \\
(-1.62)\end{array}$ & $\begin{array}{l}-0.0074 \\
(-1.66)\end{array}$ \\
\hline Book_to_Market & $\begin{array}{l}0.0040 \\
(4.16) \\
\end{array}$ & $\begin{array}{l}0.0040 \\
(4.16) \\
\end{array}$ & $\begin{array}{l}0.0040 \\
(4.19) \\
\end{array}$ & $\begin{array}{l}0.0040 \\
(4.18) \\
\end{array}$ & $\begin{array}{l}0.0037 \\
(3.93) \\
\end{array}$ & $\begin{array}{l}0.0037 \\
(3.92) \\
\end{array}$ & $\begin{array}{l}0.0037 \\
(3.92) \\
\end{array}$ & $\begin{array}{l}0.0037 \\
(3.92) \\
\end{array}$ \\
\hline NOA(t-1) & $\begin{array}{l}-0.0014 \\
(-2.59) \\
\end{array}$ & $\begin{array}{l}-0.0014 \\
(-2.57) \\
\end{array}$ & $\begin{array}{l}-0.0014 \\
(-2.57) \\
\end{array}$ & $\begin{array}{l}-0.0014 \\
(-2.55) \\
\end{array}$ & $\begin{array}{l}-0.0012 \\
(-2.43)\end{array}$ & $\begin{array}{l}-0.0012 \\
(-2.42)\end{array}$ & $\begin{array}{l}-0.0012 \\
(-2.49)\end{array}$ & $\begin{array}{l}-0.0012 \\
(-2.48)\end{array}$ \\
\hline Litigation & $\begin{array}{l}-0.0038 \\
(-0.85)\end{array}$ & $\begin{array}{l}-0.0037 \\
(-0.82)\end{array}$ & $\begin{array}{l}-0.0036 \\
(-0.81)\end{array}$ & $\begin{array}{l}-0.0035 \\
(-0.79)\end{array}$ & $\begin{array}{l}-0.0025 \\
(-0.54)\end{array}$ & $\begin{array}{l}-0.0026 \\
(-0.57)\end{array}$ & $\begin{array}{l}-0.0021 \\
(-0.47)\end{array}$ & $\begin{array}{l}-0.0023 \\
(-0.50)\end{array}$ \\
\hline Implicit_Claim & $\begin{array}{l}0.0155 \\
(2.94)\end{array}$ & $\begin{array}{l}0.0154 \\
(2.93)\end{array}$ & $\begin{array}{l}0.0159 \\
(3.01)\end{array}$ & $\begin{array}{l}0.0158 \\
(2.99)\end{array}$ & $\begin{array}{l}0.0192 \\
(3.47)\end{array}$ & $\begin{array}{l}0.0190 \\
(3.43)\end{array}$ & $\begin{array}{l}0.0201 \\
(3.65)\end{array}$ & $\begin{array}{l}0.0199 \\
(3.60)\end{array}$ \\
\hline Big5_auditor & $\begin{array}{l}0.0163 \\
(2.05) \\
\end{array}$ & $\begin{array}{l}0.0166 \\
(2.08) \\
\end{array}$ & $\begin{array}{l}0.0162 \\
(2.04) \\
\end{array}$ & $\begin{array}{l}0.0164 \\
(2.06) \\
\end{array}$ & $\begin{array}{l}0.0197 \\
(2.26)\end{array}$ & $\begin{array}{l}0.0200 \\
(2.29) \\
\end{array}$ & $\begin{array}{l}0.0198 \\
(2.27) \\
\end{array}$ & $\begin{array}{l}0.0199 \\
(2.29) \\
\end{array}$ \\
\hline Delta_GDP & $\begin{array}{l}-0.0132 \\
(-9.04) \\
\end{array}$ & $\begin{array}{l}-0.0131 \\
(-9.01) \\
\end{array}$ & $\begin{array}{l}-0.0132 \\
(-9.04) \\
\end{array}$ & $\begin{array}{l}-0.0132 \\
(-9.01) \\
\end{array}$ & $\begin{array}{l}-0.0143 \\
(-9.09) \\
\end{array}$ & $\begin{array}{l}-0.0142 \\
(-9.06) \\
\end{array}$ & $\begin{array}{l}-0.0143 \\
(-9.09) \\
\end{array}$ & $\begin{array}{l}-0.0142 \\
(-9.06) \\
\end{array}$ \\
\hline Time & $\begin{array}{l}0.0006 \\
(0.90) \\
\end{array}$ & $\begin{array}{l}0.0006 \\
(0.90) \\
\end{array}$ & $\begin{array}{l}0.0007 \\
(0.94) \\
\end{array}$ & $\begin{array}{l}0.0007 \\
(0.94)\end{array}$ & $\begin{array}{l}-0.0000 \\
(-0.02)\end{array}$ & $\begin{array}{l}-0.0000 \\
(-0.02)\end{array}$ & $\begin{array}{l}0.0000 \\
(0.05) \\
\end{array}$ & $\begin{array}{l}0.0000 \\
(0.03)\end{array}$ \\
\hline SOX_dummy & $\begin{array}{l}0.0071 \\
(1.02)\end{array}$ & $\begin{array}{l}0.0071 \\
(1.02)\end{array}$ & $\begin{array}{l}0.0070 \\
(0.99)\end{array}$ & $\begin{array}{l}0.0070 \\
(1.00)\end{array}$ & $\begin{array}{l}0.0100 \\
(1.36)\end{array}$ & $\begin{array}{l}0.0100 \\
(1.37)\end{array}$ & $\begin{array}{l}0.0089 \\
(1.21)\end{array}$ & $\begin{array}{l}0.0090 \\
(1.23)\end{array}$ \\
\hline Adjusted R-squared & 0.0095 & 0.0096 & 0.0095 & 0.0095 & 0.0100 & 0.0099 & 0.0097 & 0.0097 \\
\hline $\begin{array}{l}\text { F-statistic* } \\
\text { *all reported F-statistics } \\
\text { have p-values }<0.0001\end{array}$ & 13.03 & 12.98 & 14.74 & 14.70 & 12.07 & 11.88 & 13.58 & 13.40 \\
\hline
\end{tabular}


Table 5: Multiple Regression Results On Abnormal Expenses

Panel A: CEO Sample, 1992-2006

(We use firm-CEO clustered standard errors to compute the reported t-statistics)

\begin{tabular}{|c|c|c|c|c|c|c|c|c|}
\hline & \multicolumn{8}{|c|}{$\begin{array}{c}\text { Dependent Variable }= \\
\text { Abnormal Production Costs }\end{array}$} \\
\hline & \multicolumn{4}{|c|}{$\mathrm{N}=18247$} & \multicolumn{4}{|c|}{$\mathrm{N}=16316$} \\
\hline & Model1 & Model2 & Model3 & Model4 & Model5 & Model6 & Model7 & Model8 \\
\hline Intercept & $\begin{array}{l}-0.0093 \\
(-0.28)\end{array}$ & $\begin{array}{l}0.0683 \\
(2.67)\end{array}$ & $\begin{array}{l}-0.0713 \\
(-2.13)\end{array}$ & $\begin{array}{l}0.0190 \\
(0.76)\end{array}$ & $\begin{array}{l}0.0085 \\
(0.24)\end{array}$ & $\begin{array}{l}0.0765 \\
(2.72)\end{array}$ & $\begin{array}{l}-0.0589 \\
(-1.63)\end{array}$ & $\begin{array}{l}0.0211 \\
(0.76)\end{array}$ \\
\hline Age & $\begin{array}{l}0.0012 \\
(2.81)\end{array}$ & & $\begin{array}{l}0.0014 \\
(3.29)\end{array}$ & & $\begin{array}{l}0.0011 \\
(2.29)\end{array}$ & & $\begin{array}{l}0.0013 \\
(2.73)\end{array}$ & \\
\hline Young indicator & & $\begin{array}{l}-0.0168 \\
(-2.77) \\
\end{array}$ & & $\begin{array}{l}-0.0184 \\
(-3.07) \\
\end{array}$ & & $\begin{array}{l}-0.0157 \\
(-2.47) \\
\end{array}$ & & $\begin{array}{l}-0.0172 \\
(-2.74) \\
\end{array}$ \\
\hline Bonus\% & $\begin{array}{l}-0.0014 \\
(-0.10)\end{array}$ & $\begin{array}{l}-0.0015 \\
(-0.11)\end{array}$ & $\begin{array}{l}-0.0296 \\
(-2.05)\end{array}$ & $\begin{array}{l}-0.0294 \\
(-2.04)\end{array}$ & & & & \\
\hline Pay-earnings sensitivity & & & & & $\begin{array}{l}0.0002 \\
(2.36)\end{array}$ & $\begin{array}{l}0.0002 \\
(2.34)\end{array}$ & $\begin{array}{l}0.0002 \\
(2.40)\end{array}$ & $\begin{array}{l}0.0002 \\
(2.37)\end{array}$ \\
\hline Owner\% & $\begin{array}{l}-0.1333 \\
(-2.16)\end{array}$ & $\begin{array}{l}-0.1260 \\
(-2.06)\end{array}$ & & & $\begin{array}{l}-0.1424 \\
(-2.18)\end{array}$ & $\begin{array}{l}-0.1371 \\
(-2.13)\end{array}$ & & \\
\hline Un_option\% & $\begin{array}{l}-1.3081 \\
(-3.53)\end{array}$ & $\begin{array}{l}-1.3602 \\
(-3.67)\end{array}$ & & & $\begin{array}{l}-1.1326 \\
(-2.80)\end{array}$ & $\begin{array}{l}-1.1743 \\
(-2.90)\end{array}$ & & \\
\hline Ex_option\% & $\begin{array}{l}-1.1558 \\
(-3.77)\end{array}$ & $\begin{array}{l}-1.1456 \\
(-3.73)\end{array}$ & & & $\begin{array}{l}-1.2686 \\
(-3.90)\end{array}$ & $\begin{array}{l}-1.2634 \\
(-3.88)\end{array}$ & & \\
\hline Incentive_ratio & & & $\begin{array}{l}-0.1152 \\
(-6.78) \\
\end{array}$ & $\begin{array}{l}-0.1130 \\
(-6.69) \\
\end{array}$ & & & $\begin{array}{l}-0.1104 \\
(-6.37)\end{array}$ & $\begin{array}{l}-0.1085 \\
(-6.31) \\
\end{array}$ \\
\hline Log(MktCap) & $\begin{array}{l}-0.0161 \\
(-7.63)\end{array}$ & $\begin{array}{l}-0.0161 \\
(-7.66)\end{array}$ & $\begin{array}{l}-0.0068 \\
(-3.40)\end{array}$ & $\begin{array}{l}-0.0069 \\
(-3.44)\end{array}$ & $\begin{array}{l}-0.0168 \\
(-7.63)\end{array}$ & $\begin{array}{l}-0.0169 \\
(-7.68)\end{array}$ & $\begin{array}{l}-0.0079 \\
(-3.83)\end{array}$ & $\begin{array}{l}-0.0081 \\
(-3.90)\end{array}$ \\
\hline Leverage & $\begin{array}{l}0.1506 \\
(8.23)\end{array}$ & $\begin{array}{l}0.1506 \\
(8.22)\end{array}$ & $\begin{array}{l}0.1403 \\
(7.56)\end{array}$ & $\begin{array}{l}0.1402 \\
(7.54)\end{array}$ & $\begin{array}{l}0.1500 \\
(8.21)\end{array}$ & $\begin{array}{l}0.1501 \\
(8.22)\end{array}$ & $\begin{array}{l}0.1405 \\
(7.64)\end{array}$ & $\begin{array}{l}0.1406 \\
(7.63)\end{array}$ \\
\hline Beta & $\begin{array}{l}-0.0158 \\
(-3.15)\end{array}$ & $\begin{array}{l}-0.0163 \\
(-3.25)\end{array}$ & $\begin{array}{l}-0.0119 \\
(-2.39)\end{array}$ & $\begin{array}{l}-0.0126 \\
(-2.53)\end{array}$ & $\begin{array}{l}-0.0166 \\
(-3.15)\end{array}$ & $\begin{array}{l}-0.0170 \\
(-3.21)\end{array}$ & $\begin{array}{l}-0.0123 \\
(-2.34)\end{array}$ & $\begin{array}{l}-0.0129 \\
(-2.45)\end{array}$ \\
\hline Book_to_Market & $\begin{array}{l}0.0031 \\
(2.53)\end{array}$ & $\begin{array}{l}0.0031 \\
(2.53)\end{array}$ & $\begin{array}{l}0.0027 \\
(2.20)\end{array}$ & $\begin{array}{l}0.0027 \\
(2.20)\end{array}$ & $\begin{array}{l}0.0028 \\
(2.45)\end{array}$ & $\begin{array}{l}0.0028 \\
(2.44)\end{array}$ & $\begin{array}{l}0.0024 \\
(2.13)\end{array}$ & $\begin{array}{l}0.0024 \\
(2.13)\end{array}$ \\
\hline NOA(t-1) & $\begin{array}{l}0.0037 \\
(5.36)\end{array}$ & $\begin{array}{l}0.0037 \\
(5.40)\end{array}$ & $\begin{array}{l}0.0034 \\
(5.13)\end{array}$ & $\begin{array}{l}0.0034 \\
(5.17)\end{array}$ & $\begin{array}{l}0.0030 \\
(4.44)\end{array}$ & $\begin{array}{l}0.0030 \\
(4.48)\end{array}$ & $\begin{array}{l}0.0028 \\
(4.28)\end{array}$ & $\begin{array}{l}0.0028 \\
(4.32)\end{array}$ \\
\hline Litigation & $\begin{array}{l}-0.0292 \\
(-3.33)\end{array}$ & $\begin{array}{l}-0.0296 \\
(-3.38) \\
\end{array}$ & $\begin{array}{l}-0.0281 \\
(-3.20)\end{array}$ & $\begin{array}{l}-0.0289 \\
(-3.29)\end{array}$ & $\begin{array}{l}-0.0273 \\
(-2.99) \\
\end{array}$ & $\begin{array}{l}-0.0275 \\
(-3.01)\end{array}$ & $\begin{array}{l}-0.0253 \\
(-2.77) \\
\end{array}$ & $\begin{array}{l}-0.0258 \\
(-2.83) \\
\end{array}$ \\
\hline Implicit_Claim & $\begin{array}{l}-0.0171 \\
(-2.03)\end{array}$ & $\begin{array}{l}-0.0174 \\
(-2.08)\end{array}$ & $\begin{array}{l}-0.0150 \\
(-1.79) \\
\end{array}$ & $\begin{array}{l}-0.0157 \\
(-1.87)\end{array}$ & $\begin{array}{l}-0.0152 \\
(-1.74)\end{array}$ & $\begin{array}{l}-0.0154 \\
(-1.77)\end{array}$ & $\begin{array}{l}-0.0144 \\
(-1.66)\end{array}$ & $\begin{array}{l}-0.0150 \\
(-1.73)\end{array}$ \\
\hline Big5_auditor & $\begin{array}{l}-0.0093 \\
(-0.54)\end{array}$ & $\begin{array}{l}-0.0088 \\
(-0.50)\end{array}$ & $\begin{array}{l}-0.0093 \\
(-0.52)\end{array}$ & $\begin{array}{l}-0.0089 \\
(-0.50)\end{array}$ & $\begin{array}{l}-0.0166 \\
(-0.85)\end{array}$ & $\begin{array}{l}-0.0161 \\
(-0.82)\end{array}$ & $\begin{array}{l}-0.0154 \\
(-0.76)\end{array}$ & $\begin{array}{l}-0.0150 \\
(-0.74)\end{array}$ \\
\hline Delta_GDP & $\begin{array}{l}-0.0018 \\
(-1.18)\end{array}$ & $\begin{array}{l}-0.0017 \\
(-1.12)\end{array}$ & $\begin{array}{l}-0.0014 \\
(-0.92) \\
\end{array}$ & $\begin{array}{l}-0.0013 \\
(-0.85)\end{array}$ & $\begin{array}{l}-0.0016 \\
(-1.01) \\
\end{array}$ & $\begin{array}{l}-0.0015 \\
(-0.96)\end{array}$ & $\begin{array}{l}-0.0013 \\
(-0.86) \\
\end{array}$ & $\begin{array}{l}-0.0012 \\
(-0.79)\end{array}$ \\
\hline Time & $\begin{array}{l}0.0005 \\
(0.55)\end{array}$ & $\begin{array}{l}0.0005 \\
(0.54)\end{array}$ & $\begin{array}{l}0.0005 \\
(0.49)\end{array}$ & $\begin{array}{l}0.0004 \\
(0.45)\end{array}$ & $\begin{array}{l}0.0010 \\
(0.95)\end{array}$ & $\begin{array}{l}0.0010 \\
(0.94)\end{array}$ & $\begin{array}{l}0.0009 \\
(0.87)\end{array}$ & $\begin{array}{l}0.0009 \\
(0.84)\end{array}$ \\
\hline SOX_dummy & $\begin{array}{l}0.0230 \\
(3.42)\end{array}$ & $\begin{array}{l}0.0232 \\
(3.46)\end{array}$ & $\begin{array}{l}0.0168 \\
(2.48)\end{array}$ & $\begin{array}{l}0.0173 \\
(2.56)\end{array}$ & $\begin{array}{l}0.0220 \\
(3.18)\end{array}$ & $\begin{array}{l}0.0221 \\
(3.19)\end{array}$ & $\begin{array}{l}0.0157 \\
(2.24)\end{array}$ & $\begin{array}{l}0.0161 \\
(2.30)\end{array}$ \\
\hline Adjusted R-squared & 0.0495 & 0.0492 & 0.0533 & 0.0526 & 0.0496 & 0.0495 & 0.0525 & 0.0522 \\
\hline $\begin{array}{l}\text { F-statistic* } \\
\text { *all reported F-statistics } \\
\text { have p-values }<0.0001\end{array}$ & 16.09 & 16.19 & 17.40 & 17.59 & 14.66 & 14.74 & 15.83 & 15.97 \\
\hline
\end{tabular}


Panel B: CEO Sample, 1992-2006

(We use firm-CEO clustered standard errors to compute the reported t-statistics)

\begin{tabular}{|c|c|c|c|c|c|c|c|c|}
\hline & \multicolumn{8}{|c|}{$\begin{array}{c}\text { Dependent Variable }= \\
\text { Abnormal Discretionary Expenses }\end{array}$} \\
\hline & \multicolumn{4}{|c|}{$\mathrm{N}=18247$} & \multicolumn{4}{|c|}{$\mathrm{N}=16316$} \\
\hline & Model1 & Model2 & Model3 & Model4 & Model5 & Model6 & Model7 & Model8 \\
\hline Intercept & $\begin{array}{l}-0.0427 \\
(-1.05)\end{array}$ & $\begin{array}{l}-0.1569 \\
(-4.83)\end{array}$ & $\begin{array}{l}-0.0008 \\
(-0.02)\end{array}$ & $\begin{array}{l}-0.1236 \\
(-3.94)\end{array}$ & $\begin{array}{l}-0.0681 \\
(-1.56)\end{array}$ & $\begin{array}{l}-0.1549 \\
(-4.39)\end{array}$ & $\begin{array}{l}-0.0236 \\
(-0.54)\end{array}$ & $\begin{array}{l}-0.1205 \\
(-3.52)\end{array}$ \\
\hline Age & $\begin{array}{l}-0.0019 \\
(-3.61)\end{array}$ & & $\begin{array}{l}-0.0020 \\
(-3.90)\end{array}$ & & $\begin{array}{l}-0.0014 \\
(-2.57)\end{array}$ & & $\begin{array}{l}-0.0015 \\
(-2.89)\end{array}$ & \\
\hline Young indicator & & $\begin{array}{l}0.0225 \\
(3.21)\end{array}$ & & $\begin{array}{l}0.0236 \\
(3.39)\end{array}$ & & $\begin{array}{l}0.0196 \\
(2.66)\end{array}$ & & $\begin{array}{l}\mathbf{0 . 0 2 1 0} \\
(2.87)\end{array}$ \\
\hline Bonus\% & $\begin{array}{l}-0.0240 \\
(-1.53)\end{array}$ & $\begin{array}{l}-0.0236 \\
(-1.51)\end{array}$ & $\begin{array}{l}-0.0049 \\
(-0.30)\end{array}$ & $\begin{array}{l}-0.0050 \\
(-0.31)\end{array}$ & & & & \\
\hline Pay-earnings sensitivity & & & & & $\begin{array}{l}-0.0002 \\
(-1.06)\end{array}$ & $\begin{array}{l}-0.0002 \\
(-1.05)\end{array}$ & $\begin{array}{l}-0.0002 \\
(-1.07)\end{array}$ & $\begin{array}{l}-0.0002 \\
(-1.05)\end{array}$ \\
\hline Owner\% & $\begin{array}{l}0.0403 \\
(0.59)\end{array}$ & $\begin{array}{l}0.0274 \\
(0.41)\end{array}$ & & & $\begin{array}{l}0.0199 \\
(0.29)\end{array}$ & $\begin{array}{l}0.0129 \\
(0.19)\end{array}$ & & \\
\hline Un_option\% & $\begin{array}{l}0.3645 \\
(0.79)\end{array}$ & $\begin{array}{l}0.4534 \\
(0.97)\end{array}$ & & & $\begin{array}{l}0.2542 \\
(0.49)\end{array}$ & $\begin{array}{l}0.3096 \\
(0.59)\end{array}$ & & \\
\hline Ex_option\% & $\begin{array}{l}1.3947 \\
(3.81)\end{array}$ & $\begin{array}{l}1.3753 \\
(3.77)\end{array}$ & & & $\begin{array}{l}1.4062 \\
(3.65)\end{array}$ & $\begin{array}{l}1.3988 \\
(3.64)\end{array}$ & & \\
\hline Incentive_ratio & & & $\begin{array}{l}0.0787 \\
(4.17)\end{array}$ & $\begin{array}{l}0.0755 \\
(4.03)\end{array}$ & & & $\begin{array}{l}0.0735 \\
(3.81)\end{array}$ & $\begin{array}{l}0.0713 \\
(3.72) \\
\end{array}$ \\
\hline Log(MktCap) & $\begin{array}{l}-0.0037 \\
(-1.54)\end{array}$ & $\begin{array}{l}-0.0038 \\
(-1.57)\end{array}$ & $\begin{array}{l}-0.0103 \\
(-4.52)\end{array}$ & $\begin{array}{l}-0.0102 \\
(-4.49)\end{array}$ & $\begin{array}{l}-0.0045 \\
(-1.79)\end{array}$ & $\begin{array}{l}-0.0045 \\
(-1.76)\end{array}$ & $\begin{array}{l}-0.0106 \\
(-4.46)\end{array}$ & $\begin{array}{l}-0.0105 \\
(-4.39)\end{array}$ \\
\hline Leverage & $\begin{array}{l}-0.0693 \\
(-2.58)\end{array}$ & $\begin{array}{l}-0.0692 \\
(-2.57)\end{array}$ & $\begin{array}{l}-0.0609 \\
(-2.29)\end{array}$ & $\begin{array}{l}-0.0606 \\
(-2.28)\end{array}$ & $\begin{array}{l}-0.0539 \\
(-1.87)\end{array}$ & $\begin{array}{l}-0.0540 \\
(-1.87)\end{array}$ & $\begin{array}{l}-0.0451 \\
(-1.58)\end{array}$ & $\begin{array}{l}-0.0452 \\
(-1.58)\end{array}$ \\
\hline Beta & $\begin{array}{l}0.0571 \\
(9.21)\end{array}$ & $\begin{array}{l}0.0580 \\
(9.29)\end{array}$ & $\begin{array}{l}0.0542 \\
(8.74)\end{array}$ & $\begin{array}{l}0.0554 \\
(8.87)\end{array}$ & $\begin{array}{l}0.0557 \\
(8.36)\end{array}$ & $\begin{array}{l}0.0562 \\
(8.41)\end{array}$ & $\begin{array}{l}0.0526 \\
(7.90)\end{array}$ & $\begin{array}{l}0.0533 \\
(7.97)\end{array}$ \\
\hline Book_to_Market & $\begin{array}{l}-0.0012 \\
(-1.10)\end{array}$ & $\begin{array}{l}-0.0012 \\
(-1.11)\end{array}$ & $\begin{array}{l}-0.0008 \\
(-0.77)\end{array}$ & $\begin{array}{l}-0.0008 \\
(-0.79)\end{array}$ & $\begin{array}{l}-0.0009 \\
(-0.86)\end{array}$ & $\begin{array}{l}-0.0009 \\
(-0.85)\end{array}$ & $\begin{array}{l}-0.0006 \\
(-0.55)\end{array}$ & $\begin{array}{l}-0.0006 \\
(-0.55)\end{array}$ \\
\hline $\mathrm{NOA}(\mathrm{t}-1)$ & $\begin{array}{l}0.0021 \\
(1.37)\end{array}$ & $\begin{array}{l}0.0021 \\
(1.37)\end{array}$ & $\begin{array}{l}0.0025 \\
(1.70)\end{array}$ & $\begin{array}{l}0.0025 \\
(1.70)\end{array}$ & $\begin{array}{l}0.0023 \\
(1.45)\end{array}$ & $\begin{array}{l}0.0023 \\
(1.45)\end{array}$ & $\begin{array}{l}0.0026 \\
(1.71)\end{array}$ & $\begin{array}{l}0.0026 \\
(1.71)\end{array}$ \\
\hline Litigation & $\begin{array}{l}0.0633 \\
(6.29)\end{array}$ & $\begin{array}{l}0.0643 \\
(6.37)\end{array}$ & $\begin{array}{l}0.0627 \\
(6.23)\end{array}$ & $\begin{array}{l}0.0640 \\
(6.36)\end{array}$ & $\begin{array}{l}0.0638 \\
(6.01)\end{array}$ & $\begin{array}{l}0.0641 \\
(6.03)\end{array}$ & $\begin{array}{l}0.0627 \\
(5.89)\end{array}$ & $\begin{array}{l}0.0633 \\
(5.94)\end{array}$ \\
\hline Implicit_Claim & $\begin{array}{l}0.0618 \\
(6.20)\end{array}$ & $\begin{array}{l}0.0625 \\
(6.25)\end{array}$ & $\begin{array}{l}0.0605 \\
(6.07)\end{array}$ & $\begin{array}{l}0.0615 \\
(6.15)\end{array}$ & $\begin{array}{l}0.0576 \\
(5.45)\end{array}$ & $\begin{array}{l}0.0580 \\
(5.48)\end{array}$ & $\begin{array}{l}0.0570 \\
(5.40)\end{array}$ & $\begin{array}{l}0.0577 \\
(5.46)\end{array}$ \\
\hline Big5_auditor & $\begin{array}{l}0.0204 \\
(0.89)\end{array}$ & $\begin{array}{l}0.0196 \\
(0.86)\end{array}$ & $\begin{array}{l}0.0199 \\
(0.86)\end{array}$ & $\begin{array}{l}0.0194 \\
(0.84)\end{array}$ & $\begin{array}{l}0.0158 \\
(0.62)\end{array}$ & $\begin{array}{l}0.0152 \\
(0.60)\end{array}$ & $\begin{array}{l}0.0153 \\
(0.59)\end{array}$ & $\begin{array}{l}0.0148 \\
(0.57)\end{array}$ \\
\hline Delta_GDP & $\begin{array}{l}0.0166 \\
(7.48)\end{array}$ & $\begin{array}{l}0.0165 \\
(7.42)\end{array}$ & $\begin{array}{l}0.0163 \\
(7.38)\end{array}$ & $\begin{array}{l}0.0162 \\
(7.32)\end{array}$ & $\begin{array}{l}0.0155 \\
(6.71)\end{array}$ & $\begin{array}{l}0.0154 \\
(6.66)\end{array}$ & $\begin{array}{l}0.0154 \\
(6.66)\end{array}$ & $\begin{array}{l}0.0152 \\
(6.60)\end{array}$ \\
\hline Time & $\begin{array}{l}0.0066 \\
(5.48)\end{array}$ & $\begin{array}{l}0.0066 \\
(5.50)\end{array}$ & $\begin{array}{l}0.0067 \\
(5.67)\end{array}$ & $\begin{array}{l}0.0068 \\
(5.71)\end{array}$ & $\begin{array}{l}0.0068 \\
(5.25)\end{array}$ & $\begin{array}{l}0.0068 \\
(5.25)\end{array}$ & $\begin{array}{l}0.0070 \\
(5.42)\end{array}$ & $\begin{array}{l}0.0071 \\
(5.45)\end{array}$ \\
\hline SOX_dummy & $\begin{array}{l}-0.0184 \\
(-2.01)\end{array}$ & $\begin{array}{l}-0.0188 \\
(-2.05)\end{array}$ & $\begin{array}{l}-0.0127 \\
(-1.38)\end{array}$ & $\begin{array}{l}-0.0135 \\
(-1.47)\end{array}$ & $\begin{array}{l}-0.0150 \\
(-1.59)\end{array}$ & $\begin{array}{l}-0.0152 \\
(-1.61)\end{array}$ & $\begin{array}{l}-0.0093 \\
(-0.98)\end{array}$ & $\begin{array}{l}-0.0098 \\
(-1.02)\end{array}$ \\
\hline Adjusted R-squared & 0.0569 & 0.0562 & 0.0570 & 0.0563 & 0.0519 & 0.0518 & 0.0519 & 0.0516 \\
\hline $\begin{array}{l}\text { F-statistic* } \\
\text { *all reported F-statistics } \\
\text { have p-values }<0.0001\end{array}$ & 31.94 & 31.90 & 36.15 & 36.13 & 25.87 & 25.90 & 29.21 & 29.27 \\
\hline
\end{tabular}


Table 6: Earnings Management Suspects Analysis

Suspects are derived from 18,247 CEO sample. The firm-year is identified as a "suspect" if analysts forecasts error falls between zero and one cent per share. The analyst forecast error is defined as the difference between actual EPS and the median of all analysts' final forecasts outstanding prior to the earnings announcement date. We use firm-CEO clustered standard errors to compute the reported t-statistics.

\begin{tabular}{|c|c|c|c|c|c|c|}
\hline & \multicolumn{2}{|c|}{$\begin{array}{c}\text { Dependent Variable }= \\
\text { DA } \\
(\mathrm{N}=2,716)\end{array}$} & \multicolumn{2}{|c|}{$\begin{array}{c}\text { Dependent Variable }= \\
\text { Abnormal Prod Costs } \\
(\mathrm{N}=2,716)\end{array}$} & \multicolumn{2}{|c|}{$\begin{array}{c}\text { Dependent Variable= } \\
\text { Abnormal Disc Exp } \\
(\mathrm{N}=2,716)\end{array}$} \\
\hline & Model 1 & Model2 & Model 1 & Model 2 & Model 1 & Model 2 \\
\hline Intercept & $\begin{array}{l}0.0409 \\
(0.58)\end{array}$ & $\begin{array}{l}0.0642 \\
(1.13)\end{array}$ & $\begin{array}{l}-0.3368 \\
(-4.30)\end{array}$ & $\begin{array}{l}-0.2210 \\
(-3.03)\end{array}$ & $\begin{array}{l}0.2018 \\
(2.06)\end{array}$ & $\begin{array}{l}0.0702 \\
(0.87)\end{array}$ \\
\hline Age & $\begin{array}{l}0.0004 \\
(0.55)\end{array}$ & & $\begin{array}{l}\mathbf{0 . 0 0 1 8} \\
(1.77)\end{array}$ & & $\begin{array}{l}-0.0021 \\
(-1.62)\end{array}$ & \\
\hline Young indicator & & $\begin{array}{l}-0.0074 \\
(-0.82)\end{array}$ & & $\begin{array}{l}-0.0312 \\
(-2.28)\end{array}$ & & $\begin{array}{l}0.0383 \\
(2.45) \\
\end{array}$ \\
\hline Bonus\% & $\begin{array}{l}0.0571 \\
(2.31)\end{array}$ & $\begin{array}{l}0.0574 \\
(2.33)\end{array}$ & $\begin{array}{l}-0.0078 \\
(-0.22)\end{array}$ & $\begin{array}{l}-0.0072 \\
(-0.21)\end{array}$ & $\begin{array}{l}0.0165 \\
(0.43)\end{array}$ & $\begin{array}{l}0.0155 \\
(0.40)\end{array}$ \\
\hline Owner\% & $\begin{array}{l}-0.0209 \\
(-0.36)\end{array}$ & $\begin{array}{l}-0.0211 \\
(-0.36)\end{array}$ & $\begin{array}{l}-0.1435 \\
(-1.07)\end{array}$ & $\begin{array}{l}-0.1409 \\
(-1.08)\end{array}$ & $\begin{array}{l}0.1451 \\
(0.91)\end{array}$ & $\begin{array}{l}0.1441 \\
(0.91)\end{array}$ \\
\hline Un_option\% & $\begin{array}{l}0.5777 \\
(1.02)\end{array}$ & $\begin{array}{l}0.5783 \\
(1.02)\end{array}$ & $\begin{array}{l}-0.8549 \\
(-1.13)\end{array}$ & $\begin{array}{l}-0.8938 \\
(-1.17)\end{array}$ & $\begin{array}{l}-0.6598 \\
(-0.64)\end{array}$ & $\begin{array}{l}-0.6383 \\
(-0.62)\end{array}$ \\
\hline Ex_option\% & $\begin{array}{l}0.1296 \\
(0.27) \\
\end{array}$ & $\begin{array}{l}0.1334 \\
(0.28)\end{array}$ & $\begin{array}{l}-1.4976 \\
(-2.21) \\
\end{array}$ & $\begin{array}{l}-1.4799 \\
(-2.19) \\
\end{array}$ & $\begin{array}{l}2.3848 \\
(3.23) \\
\end{array}$ & $\begin{array}{l}2.3640 \\
(3.20) \\
\end{array}$ \\
\hline Log(MktCap) & $\begin{array}{l}-0.0030 \\
(-0.75)\end{array}$ & $\begin{array}{l}-0.0030 \\
(-0.75)\end{array}$ & $\begin{array}{l}0.0023 \\
(0.39)\end{array}$ & $\begin{array}{l}0.0023 \\
(0.40)\end{array}$ & $\begin{array}{l}-0.0126 \\
(-1.99)\end{array}$ & $\begin{array}{l}-0.0125 \\
(-2.00)\end{array}$ \\
\hline Leverage & $\begin{array}{l}-0.0396 \\
(-1.04)\end{array}$ & $\begin{array}{l}-0.0397 \\
(-1.04)\end{array}$ & $\begin{array}{l}0.1331 \\
(2.13)\end{array}$ & $\begin{array}{l}0.1329 \\
(2.12)\end{array}$ & $\begin{array}{l}-0.0582 \\
(-1.01)\end{array}$ & $\begin{array}{l}-0.0579 \\
(-1.00)\end{array}$ \\
\hline Beta & $\begin{array}{l}-0.0249 \\
(-2.61)\end{array}$ & $\begin{array}{l}-0.0248 \\
(-2.61)\end{array}$ & $\begin{array}{l}-0.0190 \\
(-1.63)\end{array}$ & $\begin{array}{l}-0.0189 \\
(-1.62)\end{array}$ & $\begin{array}{l}0.0574 \\
(3.87)\end{array}$ & $\begin{array}{l}0.0571 \\
(3.84)\end{array}$ \\
\hline Book_to_Market & $\begin{array}{l}-0.0234 \\
(-1.18)\end{array}$ & $\begin{array}{l}-0.0232 \\
(-1.17)\end{array}$ & $\begin{array}{l}0.2241 \\
(7.39)\end{array}$ & $\begin{array}{l}0.2254 \\
(7.44)\end{array}$ & $\begin{array}{l}-0.1784 \\
(-6.16)\end{array}$ & $\begin{array}{l}-0.1797 \\
(-6.21)\end{array}$ \\
\hline $\operatorname{NOA}(\mathrm{t}-1)$ & $\begin{array}{l}0.0004 \\
(0.07)\end{array}$ & $\begin{array}{l}0.0004 \\
(0.07)\end{array}$ & $\begin{array}{l}-0.0107 \\
(-1.34)\end{array}$ & $\begin{array}{l}-0.0109 \\
(-1.36)\end{array}$ & $\begin{array}{l}0.0170 \\
(1.60)\end{array}$ & $\begin{array}{l}0.0171 \\
(1.61)\end{array}$ \\
\hline Litigation & $\begin{array}{l}0.0120 \\
(1.17)\end{array}$ & $\begin{array}{l}0.0122 \\
(1.17)\end{array}$ & $\begin{array}{l}-0.0172 \\
(-1.03)\end{array}$ & $\begin{array}{l}-0.0170 \\
(-1.02)\end{array}$ & $\begin{array}{l}0.0364 \\
(1.95)\end{array}$ & $\begin{array}{l}0.0359 \\
(1.91)\end{array}$ \\
\hline Implicit_Claim & $\begin{array}{l}0.0098 \\
(0.71)\end{array}$ & $\begin{array}{l}0.0099 \\
(0.71)\end{array}$ & $\begin{array}{l}-0.0291 \\
(-1.60) \\
\end{array}$ & $\begin{array}{l}-0.0293 \\
(-1.61) \\
\end{array}$ & $\begin{array}{l}0.0657 \\
(2.86) \\
\end{array}$ & $\begin{array}{l}0.0658 \\
(2.85) \\
\end{array}$ \\
\hline Big5_auditor & $\begin{array}{l}0.0334 \\
(1.48)\end{array}$ & $\begin{array}{l}0.0333 \\
(1.48)\end{array}$ & $\begin{array}{l}-0.0055 \\
(-0.17)\end{array}$ & $\begin{array}{l}-0.0058 \\
(-0.17)\end{array}$ & $\begin{array}{l}-0.0423 \\
(-1.01)\end{array}$ & $\begin{array}{l}-0.0421 \\
(-1.00)\end{array}$ \\
\hline Delta_GDP & $\begin{array}{l}-0.0134 \\
(-3.42)\end{array}$ & $\begin{array}{l}-0.0133 \\
(-3.39)\end{array}$ & $\begin{array}{l}0.0067 \\
(1.35)\end{array}$ & $\begin{array}{l}0.0071 \\
(1.44)\end{array}$ & $\begin{array}{l}0.0097 \\
(1.60)\end{array}$ & $\begin{array}{l}0.0093 \\
(1.52)\end{array}$ \\
\hline Time & $\begin{array}{l}-0.0000 \\
(-0.02)\end{array}$ & $\begin{array}{l}-0.0000 \\
(-0.02)\end{array}$ & $\begin{array}{l}0.0045 \\
(1.75)\end{array}$ & $\begin{array}{l}0.0045 \\
(1.75)\end{array}$ & $\begin{array}{l}0.0027 \\
(0.85)\end{array}$ & $\begin{array}{l}0.0027 \\
(0.84)\end{array}$ \\
\hline SOX_dummy & $\begin{array}{l}0.0315 \\
(1.83)\end{array}$ & $\begin{array}{l}0.0315 \\
(1.83)\end{array}$ & $\begin{array}{l}-0.0091 \\
(-0.50)\end{array}$ & $\begin{array}{l}-0.0091 \\
(-0.50)\end{array}$ & $\begin{array}{l}0.0346 \\
(1.50)\end{array}$ & $\begin{array}{l}0.0347 \\
(1.50)\end{array}$ \\
\hline $\begin{array}{l}\text { Adjusted R- } \\
\text { squared }\end{array}$ & 0.0099 & 0.0100 & 0.0855 & 0.0861 & 0.0640 & 0.0649 \\
\hline $\begin{array}{c}\text { F-statistic } \\
\text { (p-value) }\end{array}$ & $\begin{array}{l}3.04 \\
(<0.0001)\end{array}$ & $\begin{array}{l}3.04 \\
(<0.0001)\end{array}$ & $\begin{array}{l}8.97 \\
(<0.0001)\end{array}$ & $\begin{array}{l}9.07 \\
(<0.0001)\end{array}$ & $\begin{array}{l}9.55 \\
(<0.0001)\end{array}$ & $\begin{array}{l}9.61 \\
(<0.0001\end{array}$ \\
\hline
\end{tabular}


Table 7: Robustness Checks

Panel A: Firm Effect Regressions

\begin{tabular}{|c|c|c|c|c|c|c|c|c|}
\hline & \multicolumn{8}{|c|}{$\begin{array}{c}\text { Dependent Variable = } \\
\text { DA }\end{array}$} \\
\hline & \multicolumn{4}{|c|}{$\mathrm{N}=18247$} & \multicolumn{4}{|c|}{$\mathrm{N}=16316$} \\
\hline & Model1 & Model2 & Model3 & Model4 & Model5 & Model6 & Model7 & Model8 \\
\hline Age & $\begin{array}{l}0.0005 \\
(2.12) \\
\end{array}$ & & $\begin{array}{l}0.0005 \\
(2.12) \\
\end{array}$ & & $\begin{array}{l}0.0005 \\
(2.10) \\
\end{array}$ & & $\begin{array}{l}0.0005 \\
(2.07) \\
\end{array}$ & \\
\hline Young indicator & & $\begin{array}{l}-0.0084 \\
(-2.41)\end{array}$ & & $\begin{array}{l}-0.0085 \\
(-2.43)\end{array}$ & & $\begin{array}{l}-0.0069 \\
(-1.91)\end{array}$ & & $\begin{array}{l}-0.0069 \\
(-1.90)\end{array}$ \\
\hline Controls & $\mathrm{Y}$ & $\mathrm{Y}$ & $\mathrm{Y}$ & $\mathrm{Y}$ & $\mathrm{Y}$ & $\mathrm{Y}$ & $\mathrm{Y}$ & $\mathrm{Y}$ \\
\hline Adjusted R-squared & 0.0104 & 0.0104 & 0.0102 & 0.0103 & 0.0109 & 0.0109 & 0.0106 & 0.0105 \\
\hline
\end{tabular}

\begin{tabular}{|c|c|c|c|c|c|c|c|c|}
\hline & \multicolumn{8}{|c|}{$\begin{array}{c}\text { Dependent Variable = } \\
\text { Abnormal Production Costs }\end{array}$} \\
\hline & \multicolumn{4}{|c|}{$\mathrm{N}=18247$} & \multicolumn{4}{|c|}{$N=16316$} \\
\hline & Model1 & Model2 & Model3 & Model4 & Model5 & Model6 & Model7 & Model8 \\
\hline Age & $\begin{array}{l}0.0012 \\
(5.46)\end{array}$ & & $\begin{array}{l}0.0014 \\
(6.41)\end{array}$ & & $\begin{array}{l}0.0011 \\
(4.53)\end{array}$ & & $\begin{array}{l}0.0013 \\
(5.41)\end{array}$ & \\
\hline Young indicator & & $\begin{array}{l}-0.0168 \\
(-4.78) \\
\end{array}$ & & $\begin{array}{l}-0.0184 \\
(-5.30) \\
\end{array}$ & & $\begin{array}{l}-0.0157 \\
(-4.30) \\
\end{array}$ & & $\begin{array}{l}-0.0172 \\
(-4.76) \\
\end{array}$ \\
\hline Controls & $\mathrm{Y}$ & $\mathrm{Y}$ & $\mathrm{Y}$ & $\mathrm{Y}$ & $\mathrm{Y}$ & $\mathrm{Y}$ & $\mathrm{Y}$ & $\mathrm{Y}$ \\
\hline Adjusted R-squared & 0.0504 & 0.0500 & 0.0540 & 0.0533 & 0.0505 & 0.0504 & 0.0534 & 0.0530 \\
\hline
\end{tabular}

\begin{tabular}{|c|c|c|c|c|c|c|c|c|}
\hline & \multicolumn{8}{|c|}{$\begin{array}{c}\text { Dependent Variable }= \\
\text { Abnormal Discretionary Expenses }\end{array}$} \\
\hline & \multicolumn{4}{|c|}{$\mathrm{N}=18247$} & \multicolumn{4}{|c|}{$\mathrm{N}=16316$} \\
\hline & Model1 & Model2 & Model3 & Model4 & Model5 & Model6 & Model7 & Model8 \\
\hline Age & $\begin{array}{l}-0.0019 \\
(-5.70)\end{array}$ & & $\begin{array}{l}-0.0020 \\
(-6.15)\end{array}$ & & $\begin{array}{l}-0.0014 \\
(-4.03)\end{array}$ & & $\begin{array}{l}-0.0015 \\
(-4.53)\end{array}$ & \\
\hline Young indicator & & $\begin{array}{l}0.0225 \\
(4.50)\end{array}$ & & $\begin{array}{l}\mathbf{0 . 0 2 3 6} \\
(4.74)\end{array}$ & & $\begin{array}{l}\mathbf{0 . 0 1 9 6} \\
(3.74)\end{array}$ & & $\begin{array}{l}\mathbf{0 . 0 2 1 0} \\
(4.02)\end{array}$ \\
\hline Controls & $\mathrm{Y}$ & $\mathrm{Y}$ & $\mathrm{Y}$ & $\mathrm{Y}$ & $\mathrm{Y}$ & $\mathrm{Y}$ & $\mathrm{Y}$ & $\mathrm{Y}$ \\
\hline Adjusted R-squared & 0.0577 & 0.0571 & 0.0578 & 0.0570 & 0.0528 & 0.0527 & 0.0527 & 0.0524 \\
\hline
\end{tabular}


Panel B: Excluding CEOs Close To Retirement

\begin{tabular}{|c|c|c|c|c|c|c|c|c|}
\hline & \multicolumn{8}{|c|}{$\begin{array}{c}\text { Dependent Variable = } \\
\text { DA }\end{array}$} \\
\hline & \multicolumn{4}{|c|}{$\mathrm{N}=15196$} & \multicolumn{4}{|c|}{$\mathrm{N}=13515$} \\
\hline & Model1 & Model2 & Model3 & Model4 & Model5 & Model6 & Model7 & Model8 \\
\hline Age & $\begin{array}{l}0.0008 \\
(2.06)\end{array}$ & & $\begin{array}{l}0.0008 \\
(2.07)\end{array}$ & & $\begin{array}{l}0.0009 \\
(2.33)\end{array}$ & & $\begin{array}{l}0.0009 \\
(2.28)\end{array}$ & \\
\hline Young indicator & & $\begin{array}{l}-0.0089 \\
(-2.23)\end{array}$ & & $\begin{array}{l}-0.0089 \\
(-2.23)\end{array}$ & & $\begin{array}{l}-0.0080 \\
(-1.92)\end{array}$ & & $\begin{array}{l}-0.0077 \\
(-1.87) \\
\end{array}$ \\
\hline Controls & $\mathrm{Y}$ & $\mathrm{Y}$ & $\mathrm{Y}$ & $\mathrm{Y}$ & $\mathrm{Y}$ & $\mathrm{Y}$ & $\mathrm{Y}$ & $\mathrm{Y}$ \\
\hline Adjusted R-squared & 0.0093 & 0.0093 & 0.0103 & 0.0103 & 0.0097 & 0.0095 & 0.0097 & 0.0095 \\
\hline
\end{tabular}

\begin{tabular}{|c|c|c|c|c|c|c|c|c|}
\hline & \multicolumn{8}{|c|}{$\begin{array}{c}\text { Dependent Variable }= \\
\text { Abnormal Production Costs }\end{array}$} \\
\hline & \multicolumn{4}{|c|}{$\mathrm{N}=15196$} & \multicolumn{4}{|c|}{$\mathrm{N}=13515$} \\
\hline & Model1 & Model2 & Model3 & Model4 & Model5 & Model6 & Model7 & Model8 \\
\hline Age & $\begin{array}{l}0.0017 \\
(2.65)\end{array}$ & & $\begin{array}{l}0.0014 \\
(2.23)\end{array}$ & & $\begin{array}{l}0.0014 \\
(2.10)\end{array}$ & & $\begin{array}{l}0.0012 \\
(1.75)\end{array}$ & \\
\hline Young indicator & & $\begin{array}{l}-0.0162 \\
(-2.58)\end{array}$ & & $\begin{array}{l}-0.0150 \\
(-2.42)\end{array}$ & & $\begin{array}{l}-0.0151 \\
(-2.31)\end{array}$ & & $\begin{array}{l}-0.0141 \\
(-2.19)\end{array}$ \\
\hline Controls & $\mathrm{Y}$ & $\mathrm{Y}$ & $\mathrm{Y}$ & $\mathrm{Y}$ & $\mathrm{Y}$ & $\mathrm{Y}$ & $\mathrm{Y}$ & $\mathrm{Y}$ \\
\hline Adjusted R-squared & 0.0510 & 0.0505 & 0.0567 & 0.0564 & 0.0514 & 0.0511 & 0.0547 & 0.0547 \\
\hline
\end{tabular}

\begin{tabular}{|l|l|l|l|l|l|l|l|l|}
\hline & \multicolumn{7}{|c|}{ Abnormal Discretionary Expenses } \\
\hline & \multicolumn{9}{|c|}{ N=15196 } & \multicolumn{3}{c|}{ N=13515 } \\
\hline & Model1 & Model2 & Model3 & Model4 & Model5 & Model6 & Model7 & Model8 \\
\hline Age & $\mathbf{- 0 . 0 0 2 4}$ & & $\mathbf{- 0 . 0 0 2 1}$ & & $\mathbf{- 0 . 0 0 1 9}$ & & $\mathbf{- 0 . 0 0 1 7}$ & \\
& $\mathbf{( - 3 . 2 7 )}$ & & $\mathbf{( - 2 . 9 3 )}$ & & $\mathbf{( - 2 . 5 2 )}$ & & $\mathbf{( - 2 . 2 3 )}$ & \\
\hline Young indicator & & $\mathbf{0 . 0 1 8 3}$ & & $\mathbf{0 . 0 1 7 2}$ & & $\mathbf{0 . 0 1 7 1}$ & & $\mathbf{0 . 0 1 6 4}$ \\
& & $\mathbf{( 2 . 4 8 )}$ & & $\mathbf{( 2 . 3 5 )}$ & & $\mathbf{( 2 . 2 1 )}$ & & $\mathbf{( 2 . 1 3 )}$ \\
\hline Controls & Y & Y & Y & Y & Y & Y & Y & Y \\
\hline Adjusted R-squared & 0.0645 & 0.0635 & 0.0660 & 0.0653 & 0.0598 & 0.0594 & 0.0599 & 0.0596 \\
\hline
\end{tabular}


Panel C: Excluding First-Year CEOs

\begin{tabular}{|c|c|c|c|c|c|c|c|c|}
\hline & \multicolumn{8}{|c|}{$\begin{array}{c}\text { Dependent Variable = } \\
\text { DA }\end{array}$} \\
\hline & \multicolumn{4}{|c|}{$\mathrm{N}=13858$} & \multicolumn{4}{|c|}{$\mathrm{N}=12525$} \\
\hline & Model1 & Model2 & Model3 & Model4 & Model5 & Model6 & Model7 & Model8 \\
\hline Age & $\begin{array}{l}0.0006 \\
(2.02)\end{array}$ & & $\begin{array}{l}0.0005 \\
(1.89)\end{array}$ & & $\begin{array}{l}0.0005 \\
(1.74)\end{array}$ & & $\begin{array}{l}0.0005 \\
(1.77)\end{array}$ & \\
\hline Young indicator & & $\begin{array}{l}-0.0090 \\
(-2.13)\end{array}$ & & $\begin{array}{l}-0.0086 \\
(-2.06)\end{array}$ & & $\begin{array}{l}-0.0076 \\
(-1.73)\end{array}$ & & $\begin{array}{l}-0.0077 \\
(-1.76) \\
\end{array}$ \\
\hline Controls & $\mathrm{Y}$ & $\mathrm{Y}$ & $\mathrm{Y}$ & $\mathrm{Y}$ & $\mathrm{Y}$ & $\mathrm{Y}$ & $\mathrm{Y}$ & $\mathrm{Y}$ \\
\hline Adjusted R-squared & 0.0089 & 0.0089 & 0.0086 & 0.0087 & 0.0088 & 0.0087 & 0.0085 & 0.0085 \\
\hline
\end{tabular}

\begin{tabular}{|c|c|c|c|c|c|c|c|c|}
\hline & \multicolumn{8}{|c|}{$\begin{array}{c}\text { Dependent Variable }= \\
\text { Abnormal Production Costs }\end{array}$} \\
\hline & \multicolumn{4}{|c|}{$\mathrm{N}=13858$} & \multicolumn{4}{|c|}{$\mathrm{N}=12525$} \\
\hline & Model1 & Model2 & Model3 & Model4 & Model5 & Model6 & Model7 & Model8 \\
\hline Age & $\begin{array}{l}0.0010 \\
(2.09)\end{array}$ & & $\begin{array}{l}0.0012 \\
(2.53)\end{array}$ & & $\begin{array}{l}\mathbf{0 . 0 0 1 0} \\
(1.83)\end{array}$ & & $\begin{array}{l}0.0011 \\
(2.19)\end{array}$ & \\
\hline Young indicator & & $\begin{array}{l}-0.0155 \\
(-2.32)\end{array}$ & & $\begin{array}{l}-0.0168 \\
(-2.52)\end{array}$ & & $\begin{array}{l}-0.0160 \\
(-2.31)\end{array}$ & & $\begin{array}{l}-0.0169 \\
(-2.45)\end{array}$ \\
\hline Controls & $\mathrm{Y}$ & $\mathrm{Y}$ & $\mathrm{Y}$ & $\mathrm{Y}$ & $\mathrm{Y}$ & $\mathrm{Y}$ & $\mathrm{Y}$ & $\mathrm{Y}$ \\
\hline Adjusted R-squared & 0.0485 & 0.0485 & 0.0513 & 0.0510 & 0.0487 & 0.0490 & 0.0511 & 0.0511 \\
\hline
\end{tabular}

\begin{tabular}{|c|c|c|c|c|c|c|c|c|}
\hline & \multicolumn{8}{|c|}{$\begin{array}{c}\text { Dependent Variable }= \\
\text { Abnormal Discretionary Expenses }\end{array}$} \\
\hline & \multicolumn{4}{|c|}{$\mathrm{N}=13858$} & \multicolumn{4}{|c|}{$\mathrm{N}=12525$} \\
\hline & Model1 & Model2 & Model3 & Model4 & Model5 & Model6 & Model7 & Model8 \\
\hline Age & $\begin{array}{l}-0.0012 \\
(-2.14)\end{array}$ & & $\begin{array}{l}-0.0014 \\
(-2.42)\end{array}$ & & $\begin{array}{l}-0.0011 \\
(-1.83)\end{array}$ & & $\begin{array}{l}-0.0013 \\
(-2.08)\end{array}$ & \\
\hline Young indicator & & $\begin{array}{l}\mathbf{0 . 0 1 8 8} \\
(2.39)\end{array}$ & & $\begin{array}{l}\mathbf{0 . 0 1 9 9} \\
(2.54)\end{array}$ & & $\begin{array}{l}.0205 \\
(2.49)\end{array}$ & & $\begin{array}{l}0.0215 \\
(2.62)\end{array}$ \\
\hline Controls & $\mathrm{Y}$ & $\mathrm{Y}$ & $\mathrm{Y}$ & $\mathrm{Y}$ & $\mathrm{Y}$ & $\mathrm{Y}$ & Y & $\mathrm{Y}$ \\
\hline Adjusted R-squared & 0.0495 & 0.0495 & 0.0492 & 0.0491 & 0.0464 & 0.0467 & 0.0460 & 0.0462 \\
\hline
\end{tabular}

